Please do not destroy or throw away this publication. If you have no further use for it, write to the Geological Survey at Washington and ask for a frank to return it

Department of The INTERTor

Ray Lyman Wilbur, Secrstary

U. S. GEOLOGICAL SURVEY

George Otis Smith, Director

Professional Paper 158-B

$\left[\begin{array}{ccc}\text { RECEIVED } \\ \text { UEC } 10 & 0 & 1929 \\ \text { L. C. } & \text { DECIUS }\end{array}\right]$

\title{
THE CONTACT OF THE FOX HILLS AND LANCE FORMATIONS
}

BY

C. E. DOBBIN AND JOHN B. REESIDE, JR.

Shorter contributions to general geology, 1929 '

(Pages 9-25)

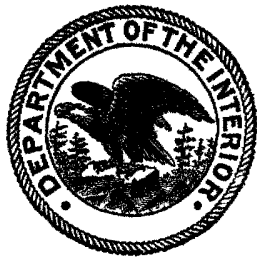

UNITED STATES

GOVERNMENT PRINTING OFFICE

WASHINGTON : 1929 


\section{CONTENTS}

Abstract

Introduction

Questions involved and general conclusions . .

Criteria for separation of the Fox Hills and Lance formations

Fox Hills and Lance formations in different regions. .

Mouth of Cannonball River, N. Dak _

Cannonball River to Fox Ridge, S. Dak

Fox Ridge to Little Missouri River, S. Dak

Marmarth, N. Dak

Marmarth, N. Dak., to Glendive, Mont. . .

Northeastern Montana

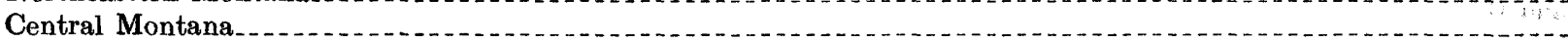

Southeastern Montana.

Ridge, Mont., to Lance Creek, Wyo

Central Wyoming

Southern Wyoming

Yampa Valley, Colo

Northeastern Colorado and the Denver Basin.

Western and southern margins of the Interior region

Constitution of the Colgate sandstone member of the Fox Hills sandstone.

Summary of conclusions.

\section{ILLUSTRATIONS}

Prate 4. A, Grayish-white sandstone at the top of the Fox Hills sandstone in the south bank of the Cannonball River $31 / 2$ miles west of Solen, N. Dak.; B, Cross-bedding in the Fox Hills sandstone (?) in the SE. 1/4 sec. 15, T. 15 N., R. 8 E., near Govert, S. Dak.; $C$, Flutings in the weathered surface of the Colgate sandstone member of the Fox Hills sandstone in the railroad cut $31 / 2$ miles west of Marmarth, N. Dak

5. $A$, Local channeling in the Fox Hills sandstone on Little Beaver Creek in the SE. $1 / 4$ sec. 7, T. 102 N., R. 106 W., N. Dak.; B, Devil Creek, in T. 21 N., R. 32 E., Mont., showing the white Colgate sandstone and associated beds; $C$, Colgate sandstone 4 miles southwest of Glendive, Mont

FIgdre 1. Index map showing distribution of the Fox Hills sandstone 2. Diagram of faulting in the Lance formation on Worthless (Trish) Creek, in the SE. $1 / 4$ sec. 23, T. 16 N., R. 20 E., S. Dak

3. Details of bedding of outcrop of Fox Hills sandstone (?) near Govert, S. Dak

4. Diagrammatic cross section across the Cedar Creek anticline at Iron Bluff, near Glendive, Mont........... II 


\title{
THE CONTACT OF THE FOX HILLS AND LANCE FORMATIONS
}

\author{
By C. E. Dobrin and John B. Reesipe, Jr.
}

\begin{abstract}
The presence or absence of an extensive unconformity at the contact between the Fox Hills and Lance formations is an important element in the problem of the Cretaceous-Tertiary boundary in the Western Interior of the United States. Proponents of the theory that an unconformity exists have rested their case primarily on a correlation of the Arapahoe and Denver formations with the Lance and Fort Union formations, the supposed absence in the northern Great Plains of the Laramie formation, the relative thinness of the Fox Hills sandstone in the northern Great Plains as compared with that in the Denver Basin, and reported angular discordances between the Fox Hills and the Lance at several localities. The present writers describe, chiefly from personal observation, the contact of the Fox Hills and Lance formations over much of the area of their occurrence and of units equivalent to these formations in areas where other names are used, paying especial attention to localities in which there are reported discordances. They advocate the view that the Laramie, Arapahoe, and Denyer formations of the Denver Basin are represented in the Lance-formation; that the differing thicknesses of the Fox Hills are original and not due to varying amounts of pre-Lance erosion; that each supposed angular discordance is due to some other phenomenon, such as local small faulting or cross-bedding; and finally, as a general conclusion, that there is no unconformity between the Fox Hills and Lance other than such as is found along local minor erosion planes at many horizons within both formations. The suspicion that the peculiar lithology of the Colgate member of the Fox Hills sandstone might be due to a content of volcanic ash is disproved by petrographic examination.
\end{abstract}

\section{INTRODUCTION}

Many papers have been published on the problem of the Cretaceous-Tertiary boundary in the Western Interior of the United States, but many points nevertheless remain in dispute. The relation between the Fox Hills and Lance formations, a cause of particularly wide divergence of opinion, has been of especial interest to the writers because of intimate concern with it in the field, and they have ventured here to review the matter and to present certain observations and opinions regarding it.

The field work upon which the paper is based, carried out at different times during the years 1921 to 1926 , covered most of the region where the Lance occurs. It included studies of the contact of the Fox Hills and Lance formations in areas that were mapped in detail; visits to localities cited by previous investigators as showing angular discordance or other marked evidence of unconformity between the formations; and examinations of the strata in areas where beds of Fox Hills age are present in formations known by other names and are overlain by nonmarine beds that are variously named.

- For historical details and references to the literature of the subject the reader may consult recent papars by Knowlton, ${ }^{1}$ Thom and Dobbin, ${ }^{2}$ and Ward. ${ }^{3}$

\section{QUESTIONS INVOLVED AND GENERAL CONCLUSIC NS}

In the nopthern Great Plains region the standard section of late Cretaceaus and early Tertiary deporits contains the following formations, in ascending ordar: Pierre shale, Fox Hills sandstone, Lance formation, Fort Union formation, and Wasatch formation. The Pierre shale contains a large marine fauna, including such characteristic ammonites as Placenticeras, scaphites of the group of Acanthoscaphites? nadosus, and baculites of the large species $B$. ovatus, $B$. compressus, and $B$. grandis. The uppermost Pierre includer group of scaphites of the genus Discoscaphites and certain other fossils that tre more abundant in and more characteristic of the fox Hitls. The Fox Fills has a large marine fauna, of which the most distinctive fossils belong to the ammanite genus Sphenodiscus. At some places the uppermost Fox Hills contrins brackish-water species which are found also in the lower part of the overlying Lance. The Lance alsp contains a great variety of fresh-water invertebrates, some reptiles, including especially the dinosaurian genus Triceratops, a few species of mammals, and a large flora. In a small area the upper part of the Lance contains a marine fauna similar to that of the Fox Hills but somewhat modified and without cephalopods. The Fort Union formation has yielded a small but characteristic fauna of fresh-water invertebrates, a fairly large fauna of primitive mammals, and a large flora. The Wasatch formation has yielded a small fauna of fresh-water invertebraters a large fauna of mammals of more modern type, and a flora like that of the Fort Union formation.

It has been generally agreed that the Pierre st ale and the Fox Hills sandstone are Cretaceous and that

1 Knowlton, F. H., The Laramie flora of the Denver Basin: U. S. Geol. Survey Prof. Paper 130, pp, 3-82, 1922.

2 Thom, W. T., jr., and Dobbin, C. E., Stratigraphy of the Cretaceous-E cone transition beds in eastern Montana and the Dakotas: Geol. Soc. America Bull., vol. 35, pp. 500-506, 1924.

${ }^{3}$ Ward, Freeman, The Lance problem in South Dakota: Am. Jour. Sci., 5th ser., vol. 7, pp. $65-68,1924$. 
SHORTER CONTRIBUTIONS TO GENERAL GEOLOGY, 1929

the Wasatch formation is Eocene. Concerning the intermediate formations-the Lance and the Fort Union-three views have been expressed. One view is that the base of the Wasatch formation is the proper plane of division between the Cretaceous and the Eocene because the Fort Union is apparently inseparable from the Lance, which contains dinosaurs, whereas the Wasatch contains modern types of mammals, and because a pronounced discordance at many places indicates pre-Wasatch orogeny. Another view is that the contact of the Fort Union and Lance formations indicates the boundary between the Cretaceous and the Eocene because the Lance formation contains the latest known dinosaurs, the Lance invertebrates are more like those of the Cretaceous, and the marine member of the Lance, which is the final marine deposit in the whole Western Interior region, is Cretaceous in aspect, though at most places the contact with the Fort Union appears transitional. A third view is that the Lance and Fox Hills are separated by a hiatus of great magnitude, which is the first after a great unbroken sequence of Cretaceous deposits and which therefore constitutes the proper plane of division between the Cretaceous and the Eocene.

The question whether the Lance and Fox Hills formations are or are not separated by a great unconformity' therefore becomes an important element in the general problem, and the history of the view that such an unconformity exists will be of interest here. This view arose from a comparison of the stratigraphy in northeastern Wyoming, eastern Montana, and adjoining portions of North and South Dakota with the stratigraphy of the Denver Basin in Colorado, where the detailed studies of Emmons, Cross, and Eldridge ${ }^{4}$ were believed to have established the following propositions: The Cretaceous sea of the Western Interior invaded a region of low relief; there were no upward movements and no eroded areas of great size within the borders of this region until the end of Cretaceous time; there was, near the end of Cretaceous time, a passage into conditions of nonmarine sedimentation expressed by the Laramie formation; then followed an inception of mountain building over the present site of the Rocky Mountains and a period of active erosion, during which the sediments at places were stripped down to the pre-Cambrian; and a new set of deposits was then formed, resting in the Denver Basin itself on the eroded Laramie and beginning with the conglomerate of the Arapahoe formation.

The nonmarine Laramie formation was reported to contain a distinctive flora and a brackish and fresh water invertebrate fauna and to rest conformably upon the highest marine Upper Cretaceous beds in the basin, the Fox Hills sandstone. The conglomerate of the Arapahoe formation was reported to contain pebbles

${ }^{4}$ Emmons, S. F., Cross, Whitman, and Eldridge, G. H., Geology of the Denver Basin in Colorado: U. S. Geol. Survey Mon. 27, 1896. derived from all the older rocks in the adjacent mountains, indicating the long period of mountain making and erosion that preceded. The succeeding Denver formation was reported to consist largely of andesitic débris not seen in the Arapahoe, a fact that implies the elapse of the time necessary for the extrusion and erosion of the volcanic materials after the deposition. of the Arapahoe. The Denver and Aranahoe formations were reported to contain a distir stive flora. and a dinosaurian fauna that included the genus. Triceratops.

In early discussions ${ }^{5}$ the Arapahoe and $\Gamma$ anver were referred to the Tertiary, and the Laramie was left in the Cretaceous. In the monograph on the Denver Basin, in consideration of the dinosaurian fauna and despite the great hiatus believed to exist reneath the Arapahoe, both Arapahoe and Denver were placed in the Cretaceous. In later papers, chiefly because of the evidence of diastrophism between Laramie and Arapahoe time, the Laramie was considered by $\mathrm{Cross}^{6}$ to be the uppermost Cretaceous and the Arrpahoe and Denver formations to be Tertiary. The Triceratops fauna in the post-Laramie beds was considered a relic of the Mesozoic fauna that lived on into Tertiary time.

In the 20 years that followed the publicetion of the Denver Basin monograph the Fox Hills sandstone and overlying strata at many places in northeastern Wyoming, eastern Montana, and western North and South Dakota were examined in detail by geologists of the United States Geological Survey, who did not find a thick Fox Hills formation, a typical Laramie flora, nor a conglomerate similar to the Arapahoe of the Denver Basin. On the contrary, a Triceratops $f \varepsilon$ una and a flora identified as like that of the Fort Union formation, which is widely accepted as Tertiary, were found in the Lance formation, directly above the relatively thin Fox Hills sandstone, and in the santstone was found the same distinctive Cretaceous faura as in the Denver Basin. For some geologists the only answer to the query thus raised seemed to be that the "Triceratops beds" (the Lance formation) arn separated from the underlying marine Fox Hills sandstone by the same great unconformity as that supposed to be marked by the conglomerate of the Arapahos formation in the Denver Basin; that erosion was greater in the north than in the Denver Basin; and that in the north there are no strata equivalent in time to the Laramie formation and part of the Fox Hills formation. In the north, however, no suitable plane of ur monformity was at first observed, owing to the absence of a conglomerate similar to that of the Arapahos. Further search revealed local details that were interpreted by some geologists as proof of a widespread and at some

5 See, for example, Cross, Whitman, The Denver Tertiary formation: Am. Jour. Sci., 3d ser., vol. 37, pp. 261-282, 1889.

- Cross, Whitman, The Laramie formation and the Shoshone group: Washington Acad. Sci. Proc., vol. 11, pp. 27-45, 1909; Are the Lance and Fort Union formations. of Mesozoic time?; Science, new ser., vol. 53, pp. 304-308, 1921. 
places angular unconformity between the Fox Hills and Lance formations.

The interpretation of geologic history given above, the assignment of a great time value to the unconformity in the Denver Basin, and the evidence of the presence of a corresponding unconformity farther north have been vigorously disputed, and a list of papers contributed to the discussion is long. The strongest support for the theory of a large hiatus beneath the Lance formation lies in the supposed existence of an angular unconformity due to deformation and erosion, and no other specific explanation of some of this important physical evidence has yet been published.

In brief, then, the specific question to be considered here is whether the Lance formation rests conformably on the Fox Hills sandstone, or whether there is immediately beneath the Lance a great hiatus that represents the time required for the deposition of a considerable thickness of beds and for the occurrence of notable events in the geologic history of the Western Interior region. The writers' answer to this question is that there is nowhere in the areas considered a great unconformity between the Fox Hills and Lance formations and at most localities not even a minor one.

\section{CRITERIA FOR SEPARATION OF THE FOX HILLS AND} LANCE FORMATIONS

In a consideration of the nature of the boundary between the Lance and Fox Hills formations one must first determine what criteria shall be used for identifying the two formations and thus settle upon a means of locating the boundary between them. In general, minor individual lithologic units are not persistent in either the Fox Hills or the Lance. On the other hand, larger lithologic units, aggregations of these smaller, variable units, persist over large areas and are trustworthy features for identification. In some places, however, there is little lithologic distinction between beds that contain characteristic Lance species and others that contain characteristic Fox Hills species, and in these places the fossils must be made the chief reliance for separating the formations.

In eastern Montana, western North and South Dakota, and northeastern Wyoming the Fox Hills formation usually consists of an upper white sandstone (in eastern Montana called the Colgate sandstone member), beneath which occur alternating beds of gray, yellow, and buff sandstone and sandy shale. As noted on page 9 , this formation contains a marine fauna, in part characteristic but in part similar to that found in the upper part of the underlying Pierre shale. Locally a brackish-water fauna that contains an admixture of marine forms occurs at the top of the formation. At and west of Glendive, Mont., the Colgate member contains only fossil plants, though the lower member of the formation contains a few marine invertebrates. Here both the lithology and the marine fauna are of assistance in identification.

In central and southern Wyoming and northwestern Colorado marine forms characteristic of the Fox Hills occur in sandstones that have been interpreted at some places as part of the Lewis shale and at others as part of the overlying beds, variously named, but.thare is no definite, separable Fox Hills formation. 'T' 9 beds immediately below the horizon of these Fox Hills fossils are in part nonmarine, and the beds above are all nonmarine. Here the marine fossils alone are characteristic.

With the exception of the Cannonball marine member in a small area in North and South Dakota, the Lance formation of Montana, the Dakotas, and eastern Wyoming is of nonmarine origin. The lorer part is made up of somber-colored sandy shale alternating with lenticular beds of buff or brown sandstone and thin beds of coal. The contained fossils include plants, reptiles, especially dinosaurs of the genus Triceratops, and a few mammals. The fact that vertebrate remains are especially abundant near the base of the Lance provides an excellent criterion for separating it from the underlying Fox Hills fornation in areas where the lithology is similar, but at many places the lithology also is of great service. The upper 75 to 350 feet of the Lance usually consists of soft buff and cream-colored calcareous sandstone and shale with numerous beds of coal.

In central Wyoming the Lance formation consirts of interbedded fine-grained tan sandstone, light-gray shale, and thin layers of carbonaceous shale and cxal and is not conveniently divisible into members. It contains, however, the same nonmarine fossils as the Lance of the areas to the east and north.

In southern Wyoming and northwestern Colore do beds believed by the writers to be the equivalent of the Lance formation, though known by several lonal names, have the same lithology as the Lance of central Wyoming.

\section{FOX HILLS AND LANCE FORMATIONS IN DIFFERENT REGIONS}

In setting forth the local features on which is founc'ed the general conclusion that there is nowhere an important unconformity between the Lance and the Fox Hills the data are presented by convenient g:ographic units, recognizable on Figure 1.

\section{MOUTH OF CANTONBALL RIVER, N. DAK.}

In the area near the mouth of the Cannonball $\mathrm{Ri}^{\mathrm{r}} \mathrm{rer}$ the gray-white sandstone at the top of the Fox Hills forms a variable upper part of an upper member of the formation. The remainder of the member consi ${ }^{\text {ths }}$ of light-gray. clayey sandstone and olive-colored sandy shale; the two parts together attain a thickness of 100 feet. Above the white sandstone and to all appear- 
ances conformable with it are thick beds of impure lignite and carbonaceous shale of the Lance formation. (See pl. 4, A.) The lower member of the Fox Hills in this area is a thick-bedded yellowish-brown sandstone about 100 feet thick. Further details regarding the character of the Fox Hills in this area are given by

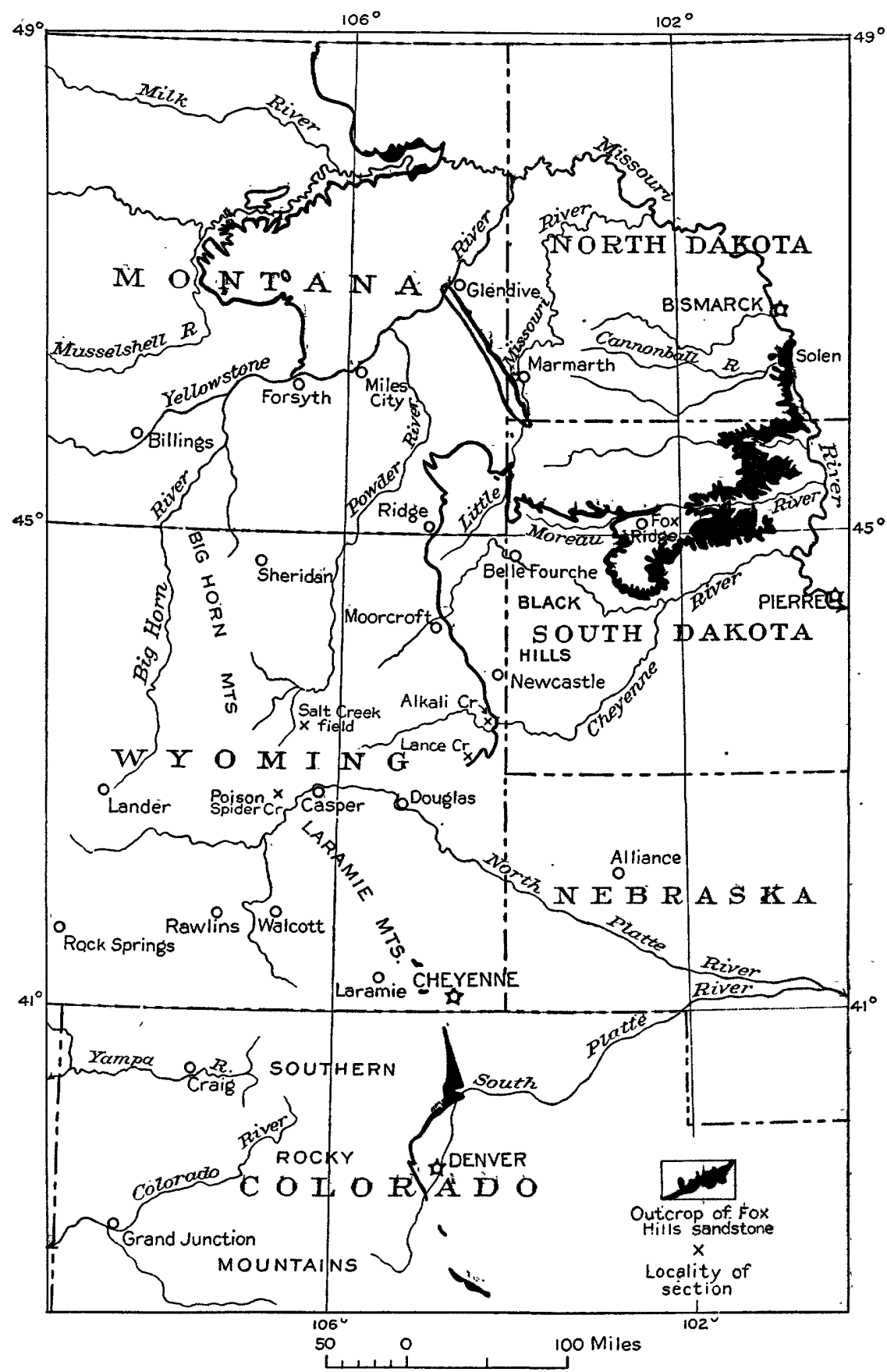

FIGURE 1.-Index map showing distribution of the Fox Hills sandstone. Certain outcrops in central south Dakota and eastern Colorado and beds of Fox Hills age included in other formations in central Wyoming and western Colorado are not shown

Leonard. ${ }^{7}$ A fairly representative section of the beds exposed on the Cannonball River is as follows:

${ }^{7}$ Leonard, A. G., The Cretaceous and Tertiary formations of western North

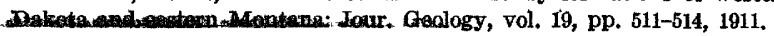

Section of parts of Fox Hills and Lance formation on south bank of Cannonball River 31/2 miles west of Solen. N. Dak.

Lance formation (basal pairt): Irregular assemblage of purple and gray shale and gray sandstone. Lignite. . .

Purple carbonaceous shale. Fox Hills formation:

Sandstone, white, more resistant than inclosing beds; contains many casts of roots . . . . . .

Sandstone, grayish white, soft; weathers into fluted crannels; contains many layers and concretions of ferruginous brown sandstone and Halymenites major throughout (see pl. 4) .........

Large concretions of cinnamonbrown sandstone.

Shale, olive-colored, gandý ....... Sandstone, brown, thick bedded, several feet; top of lowe miember.

Level of the Cannonball River.

Both members of the Fox Hills contain throughout Halymenites major, a fossil believed to be a usabla criterion of marine origin. The lower member at the west end of the railroad cut one-third of a mile west of Solen, N. Dak., yielded, at a horizc $\eta 30$ feet below the top, Pteria nebrascana Evans and Shumard, P. linmuaeformis Evans and Shumard, Tellina scitula Moek and Hayden, and Mactra formosa Meek and Hayden, all of which are long-ranging sf scies that serve only to confirm the indication of Halymenites that the beds are márine.

The fox Hills near the mouth of the Cannonball River; therefore, shows two niembers and is' appintrintly conformatile beneath the Latice beds. Sbme hurintreds of feet hig or in the section the Cantionball matine member of the Lance appears with a large faund so simithr to thit of the for tifills as to suggest thet no longt period could hate intervened in addition to that during rhich the lower Lance sediments were being laid downn.

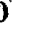


findings of Stanton, ${ }^{8}$ who reports that the Fox Hills exhibits much evidence of irregular deposition, channeling between beds, and variability in thickness, but that it nowhere shows evidence of a major break at its top. The occurrence at isolated localities in this area at or near the top of the Fox Hills of beds that have an irregular base and contain a fauna of chiefly brackishwater species has led to the assumption of a widespread unconformity beneath these beds and the selection of this unconformity as the "pre-Tertiary" break." The beds immediately above the "hiatus," however, contain a number of significant species of the Fox Hills fauna and preclude an interruption greater than that represented by any one of the admittedly minor erosion planes present in both Fox Hills and Lance formations. The fossils are delicate shells that would show any reworking very distinctly. Although the white sandstone of the upper Fox Hills was largely concealed along the route followed by the writers through this area, its presence locally is attested by Calvert, who says: ${ }^{10}$ "In some areas the lignite-bearing beds of the Lance abruptly change to the white marine sandstone of the Fox Hills, but in others the rocks of the two formations are very similar and no hard and fast line can be drawn between them."

Particular attention was paid to the locality on Worthless Creek (locally known as Irish Creek), in the SE. $1 / 4$ sec. 23, T. 16 N., R. 20 E., where Calvert ${ }^{11}$ observed what he regarded as an angular unconformity between the Fox Hills and the Lance that is cited a number of times in the literature. ${ }^{12}$ Calvert's description is as follows:

On Worthless Creek, in T. 16 N., R. 20 E., where exposures are especially good, the most striking example of unconformity between the Fox Hills and Lance formations was observed. On the west side of the Worthless Creek Valley, near the line between secs. 25 and 26 , the "somber beds" of the Lance formation transgress across the Fox Hills sandstone, and the upper part of the Fox Hills down to the banded shale is absent. The unconformity at this locality is angular as well as erosional, for the banded shale dips $4^{\circ} \mathrm{N}$., whereas the Lance is horizontal. A section of the strata 500 feet long reveals the Lance filling a channel eroded in the banded shale of the Fox Hills to a depth of 40 feet, so that the vertical amount of combined transgression and erosion is at least that amount. On the opposite side of the valley the undoubted Fox Hills is believed to be absent

8 Stanton, T. W., Fox Hills sandstone and Lance formation ("Ceratops beds") in South Dakota, North Dakota, and eastern Wyoming: Am. Jour. Sci., 4th ser., vol. 30, pp. 173-182, 1910 .

9 Knowlton, F. H., Further data on the stratigraphic position of the Lance formation ("Ceratops beds"): Jour. Geology, vol. 19, pp. 362-369, 1911.

10 Calvert, W. R., and others, Geology of the Standing Rock and Cheyenne River Iridian Reservations, N. and S. Dak.: U. S. Geol. Survey Bull. 575, p. 18, 1914.

11 Idem, p. 18.

12 Knowiton, F. H., Further data on the stratigraphic position of the Lance formation ("Ceratops beds"): Jour. Geology, vol. 19, p. 346, 1911; Cretaceous-Tertiary boundary in the Rocky Mountain region: Geol. Soc. America Bull., vol, 25, p. 327, 1914. and the lignitic zone of the Lancests on a brown banded. shale, which may represent the top of the Pierre or ma be part. of the Fox Hills. In any evert, there is surely less t1 4 . 25 feet of Fox Hills present at this place. In view of the 1 at. that the Fox Hills sandstone is normatly at least 150 feet thit $t$; it seems that the time during which orosion took place wait considerable duration.

The writers visited this locality early in May, wi the outerops were not hidden by regetation and itwres possible to study the structural relations in detail. most casual inspection under such conditions the w. that the "unconformity" is due to a small fault whin has displaced a carbonacoous shale bed about 20 t the downthrown bed dipping into the fault at an an of about $4^{\circ}$. (See fig. 2.) Dinosaur bones at the base of the bluffs indicate that the beds in the experre are Lance rather than Fox Hills, and this fact explatins why Calvert failed to find Fox Hills beds on the opposite side of the valley. There is probably a secrid

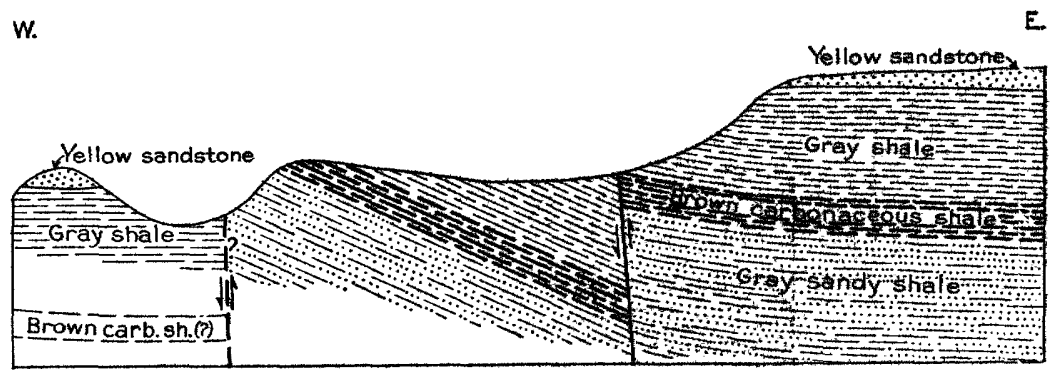

23, T. 16 N., R. 20 E., S. Dak. The throw is about 20 feet

small fault a few hundred feet away, though its presence is not very clearly shown.

Wilson and Ward ${ }^{13}$ report that the contact of the Fox Hills and Lance is transitional in the. Worthless Creek district and that the lowest bed of coal or carbonaceous shale in the Lance occurs just above an oyrter bed that marks the top of the Fox Hills over a rather broad area. That small faulting is common in the whole area is also evident from their work and from that of Russell..$^{14}$ A small fault of the same type as the one at Worthless Creek is clearly shown on the north bank of the Moreau River about 11 miles past of Bixby, in sec. 15, T. 14 N., R. 14 E., where a throw of 35 feet introduces a local dip of $4^{\circ}$ in beds that probably constitute the upper part of the Fox Hills. An example of irregularities of deposition is well shown on the bank of the Moreau River at Bixby. The uF yer part of the exposure may be Lance, but even so the relations between the irregular beds are so intricate that it is unreasonable to pick out any plane in the sequence as more significant than the rest.

${ }^{13}$ Wilson, R. A., and Ward, Foeman, The possibilities of oil in northera Zinbath County: South Dakota Geol. and Nat. Hist. Survey Oinc. 13, pp. 6-7, 102s.

1. Russell, W. L., The possibilities of oil in western Ziebach Connty: South Dakota Geol. and Nat. Hist. Survey Circ. 20, pp. 12-23, 1925. 
FOX RIDGE TO LITTLE MISSOURI RIVER, S. DAK.

From Fox Ridge westward to the Little Missouri River the contact of the Fox Hills and Lance is, as a rule, exposed only in the more or less isolated bluffs along stream valleys. Practically all outcrops of both formations near their contact show local channeling, cross-bedding, faulting, and slumping on a small scale. The Fox Hills is about 125 feet thick and consists of light-colored marine sandstone which is overlain by the basal coal-bearing beds of the Lance. No distinct or persistent division into a lower yellow sandstone and an upper white sandstone could be recognized, though it must be admitted that the outcrops are scarcely adequate.

One locality that received particular attention in the area west of Fox Ridge was that in the SE. $1 / 4$ sec. 15, T. 15 N., R. 8 E., South Dakota, 1 mile south of Govert post office, which has been reported by several writers as showing an angular unconformity between
The sandstone and conglomerate capping some of the high buttes on the divide between the Belle Fourche and Owl Rivers, northeast of Belle Fourche, S. Dak., which have been doubtfully called the Fox Hills sandstone, ${ }^{16}$ are of White River (Olig reene) age, according to Rubey, ${ }^{17}$ who has examined them in detail.

As a brief summary, it may be said that all data obtained by the writers regarding the contact of the Fox Hills and Lance in South Dakota arn in accord with the findings of Ward, ${ }^{18}$ who says: "It seems plain that the evidence points consistently and convincingly to the fact that there is no sharp or welldefined break between the Fox Hills and Lancecertainly no break which would warrant a dirision between the Mesozoic and Cenozoic."

MARMARTH, N. DAK.

At the south end of the Cedar Creek antieline, in the vicinity of Marmarth, N. Dak., the cor tact of the

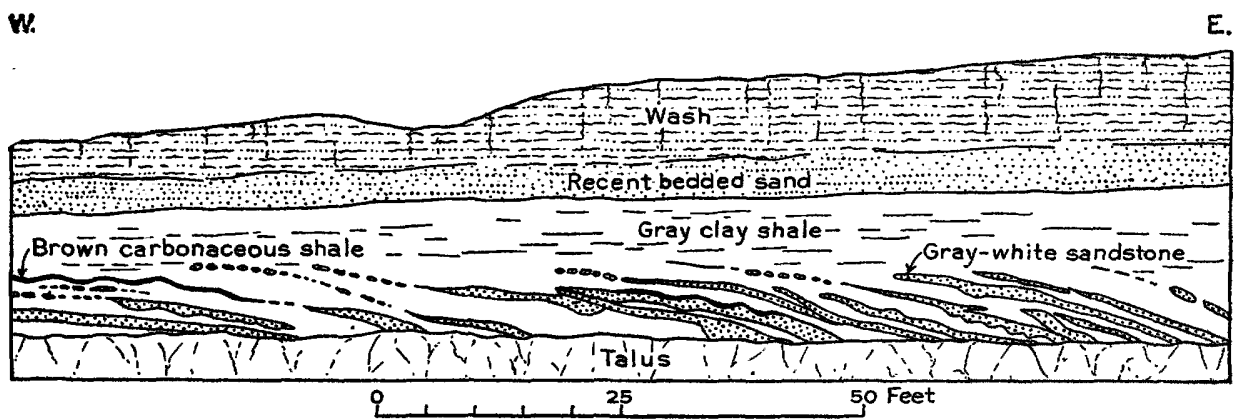

Figure 3.-Details of bedding of outerop of Fox Hills sandstone (?) in the SE. 1/4 sec. 15, T. 15 N., R. 8 E., near Govert, S. Dak. Length of section shown, 125 feet, drawn to scale. Part of this outcrop is shown in Plate 4, $B$

the Fox Hills and the Lance. ${ }^{15}$ The exposure at this locality is shown in Plate $4, B$, and exhibits the following section:

Section on bank of Moreau River near Govert, S. Dak.

Dark-colored wash and soil.

Recent sand

Sandstone and sandy shale with topset and foreset bedding $\quad 18$ Talus.

A detailed examination of this exposure shows that the inclined bedding planes represent merely foreset bedding and are not a result of folding and erosion. The sketch in Figure 3, made to scale, gives the details of bedding not clearly visible in the photograph. No evidence could be obtained to indicate the age of the individual beds in this outcrop, and it is not possible to assign them definitely to either the Lance formation or the Fox Hills sandstone.

is Knowiton, F. H., Further data on the stratigraphic position of the Lance formstion ("Ceratcps beds"): Jour. Geology, vol. 19, p. 367, 1911; CretaceousTertiary boundary in the Rocky Mountain region: Geol. Soc. America Bull., vol. 25, p. 327, 1914. Calvert, W. R., and others, op. cit., p. 19.
Fox Hills and Lance exhibits all the characteristics cbserved farther east. On Little Beaver Creek in the SE. $1 / 4$ sec. 7, T. 132 N., R. 106 W., the transition zone between the typical Pierre shale and the.basal Fox Hills sandstone is about 40 feet thick. Through this zone the roek grades upward into a soft yellowish massive - sandstone about 50 feet thick, which is overlain by the grayish-white sandstone that is seen farther east and is now known in eastern Montana as the Colgate sandstone member of the Fox Hills formation. The top of the Colgate sandstone shows local channels (see pl. $5, A$ ), which have been interpreted to indicate an unconformity. ${ }^{19}$ The section at this locality is as follows:

16 Darton, N: H., U. S. Geol. Survey Geol. A tlas, Belle Fourct a follo (No. 164), p. 5,1909

17 Rubey, W. W., personal communication.

18 Ward, Freeman, The Lance problem in Sotath Dakota: Am. J vur. Sei., 5th ser., vol. 7, p. 67, 1924.

${ }^{18}$ Leonard, A. G., The geology of southwestern North Daknta with special reference to coal: North Dakota Geol. Survey Fifth Bienn. Rept., pp. 43-44, 1908. Knowlton, F. H., The stratigraphic relations and paleontology of the "Hell Oreek beds," "Ceratops beds," and equivalents and their reference tc the Fort Union formation: Washington Acad. Sci. Proc., vol. 11, pp. 201-202, 1909. 


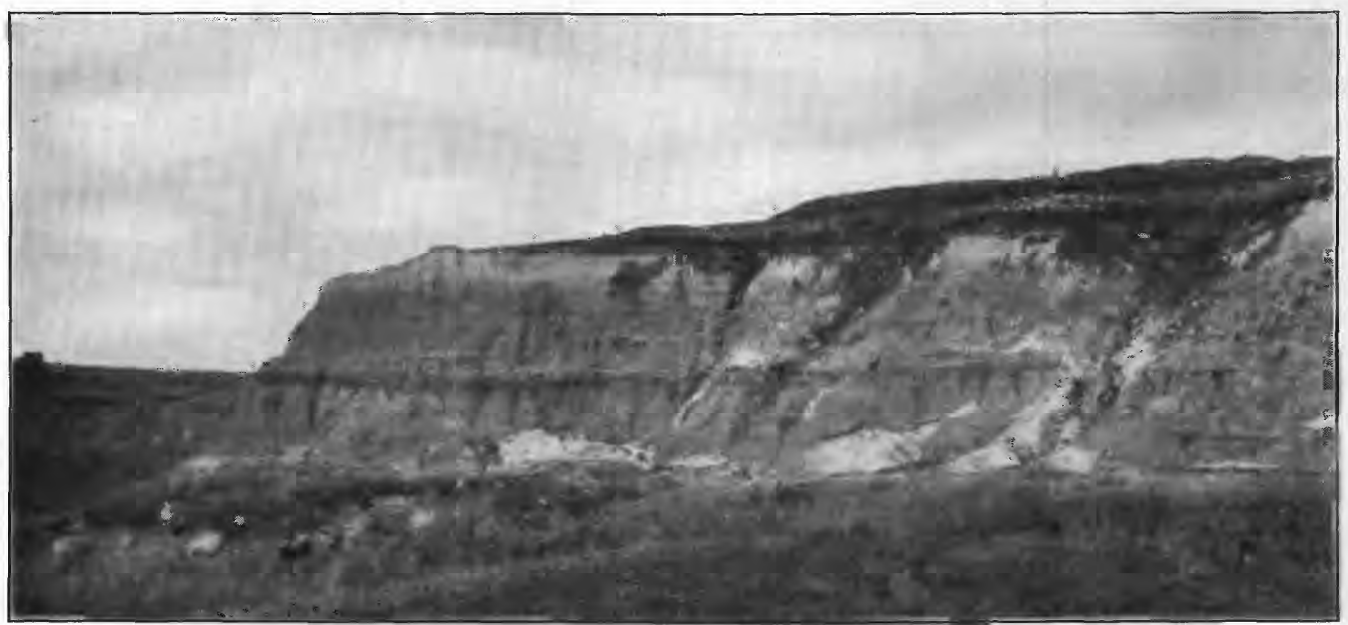

A. GRAYISH-WHITE SANDSTONE AT THE TOP OF THE FOX HULIS SANDSTONE IN THE SOUTH BANK OF THE CANNONBALL RIVER $3 \frac{1}{2}$ MILES WEST OF SOLEN, N. DAK.

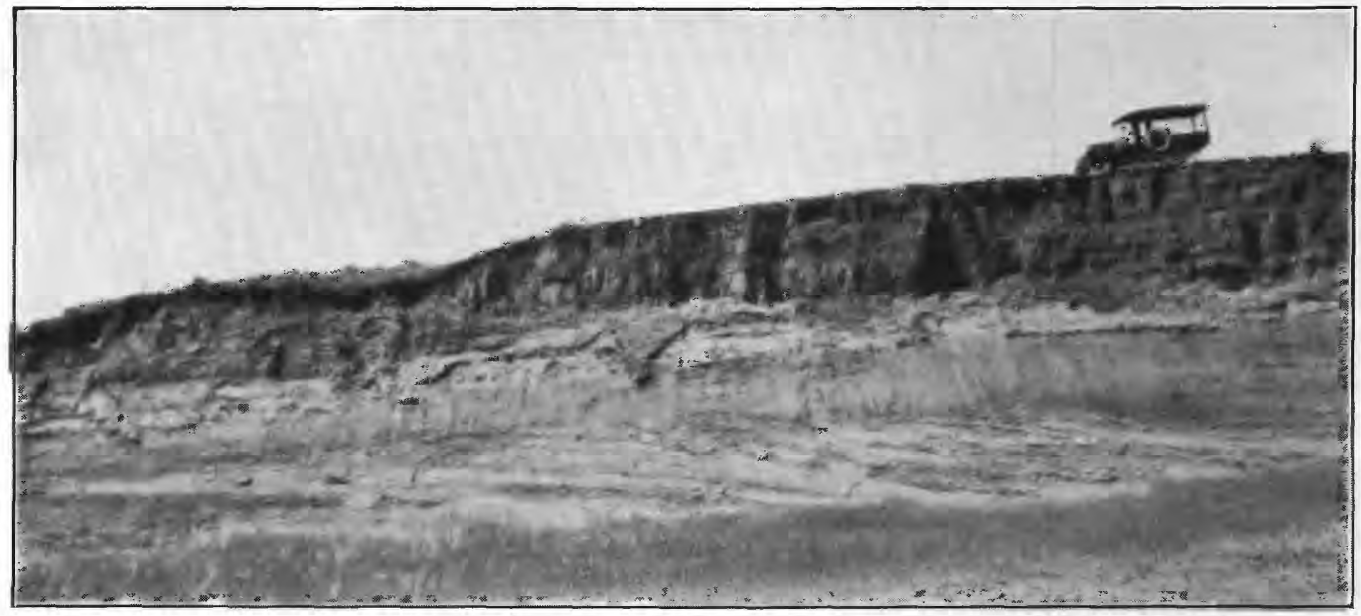

B. CROSS-BEDdiNG IN THE FOX HILls SANDSTONE (9) IN THE SE. 1/2 SEC. 15, T. 15 N., R. 8 E., NEAR GOVERT, S. DAK.

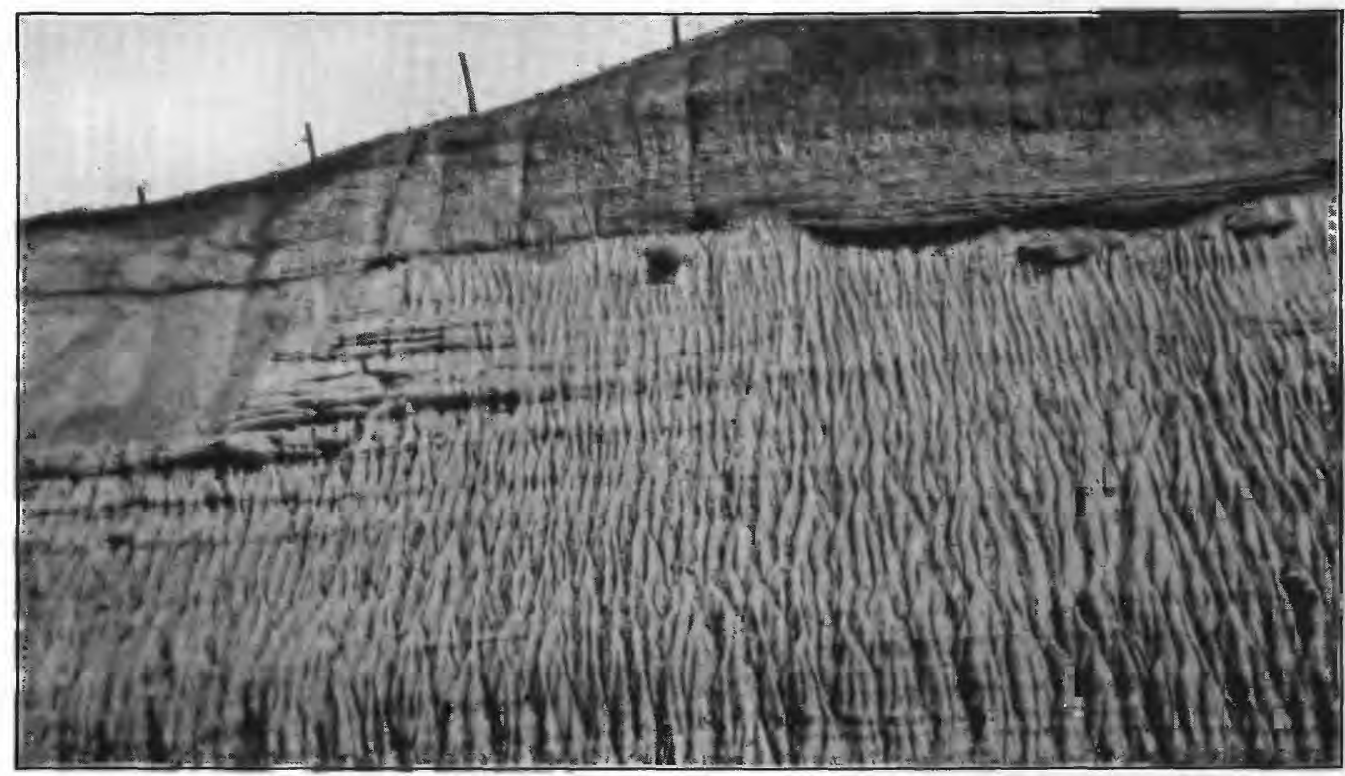

C. FLUTINGS IN THE WEATHERED SURFACE OF THE COLGATE SANDSTONE MEMBER OF THE FOX HILLS SANDSTONE IN THE RAILROAD CUT 31/2 MILES WEST OF MARMARTH, N. DAK. 


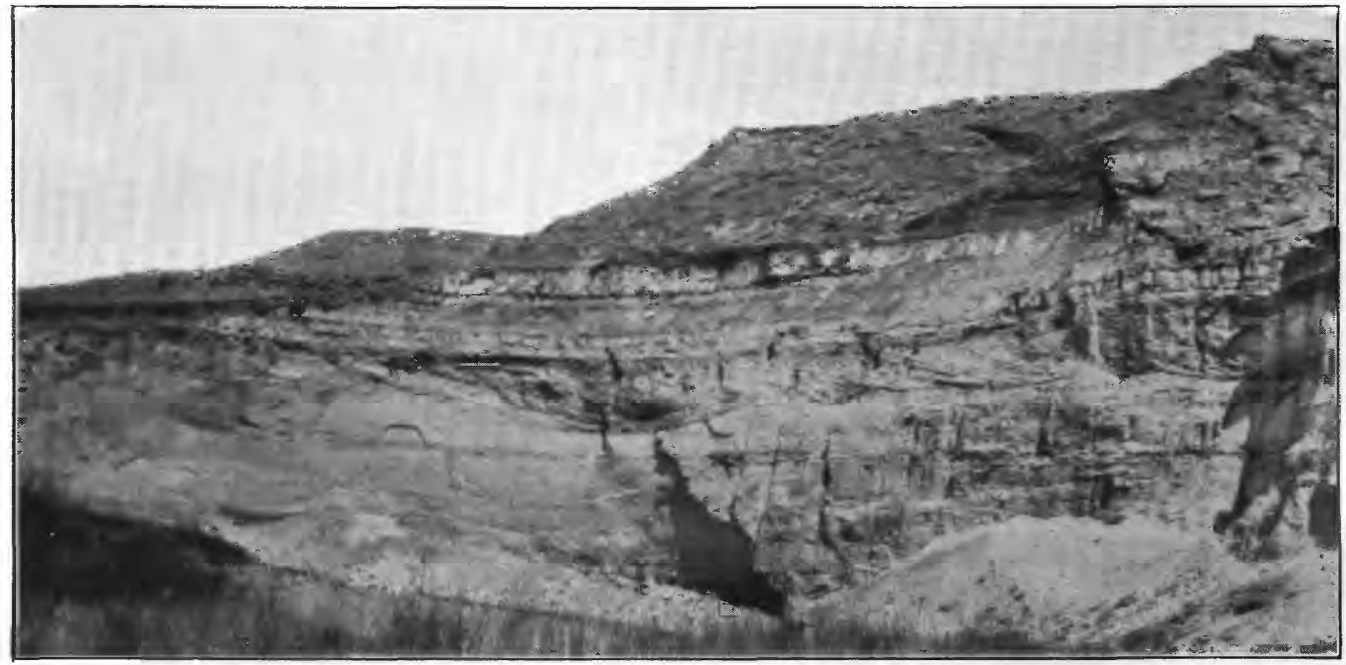

A. LOGAL CHANNELING IN THE FOX HILLS SANDSTONE ON LITTLE BEAVER CREEK IN THE SE. 1/1 SEC. 7, T. 102 N., R. 106 W., NORTH DAKOTA

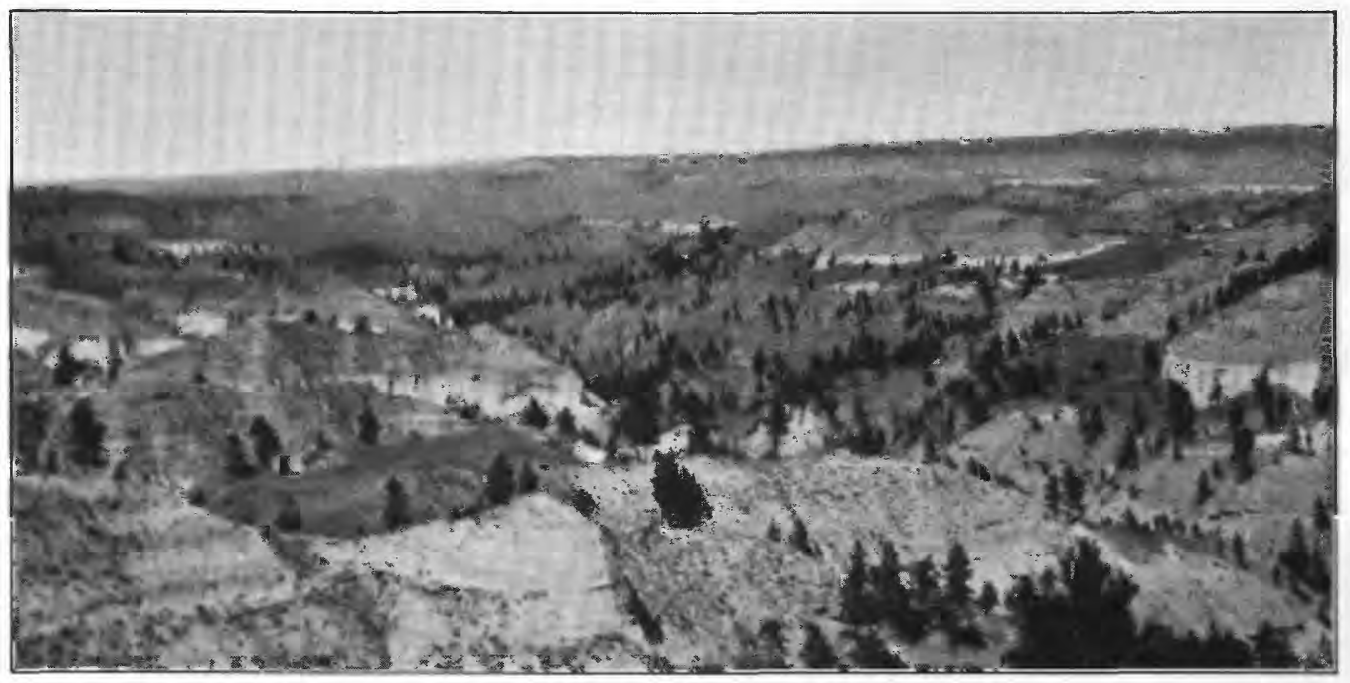

B. DEVIL CREEK, IN T. 21 N., R. 32 E., MONTANA, SHOWING THE WHITE COLGATE SANDSTONE AND ASSOCIATED BEDS

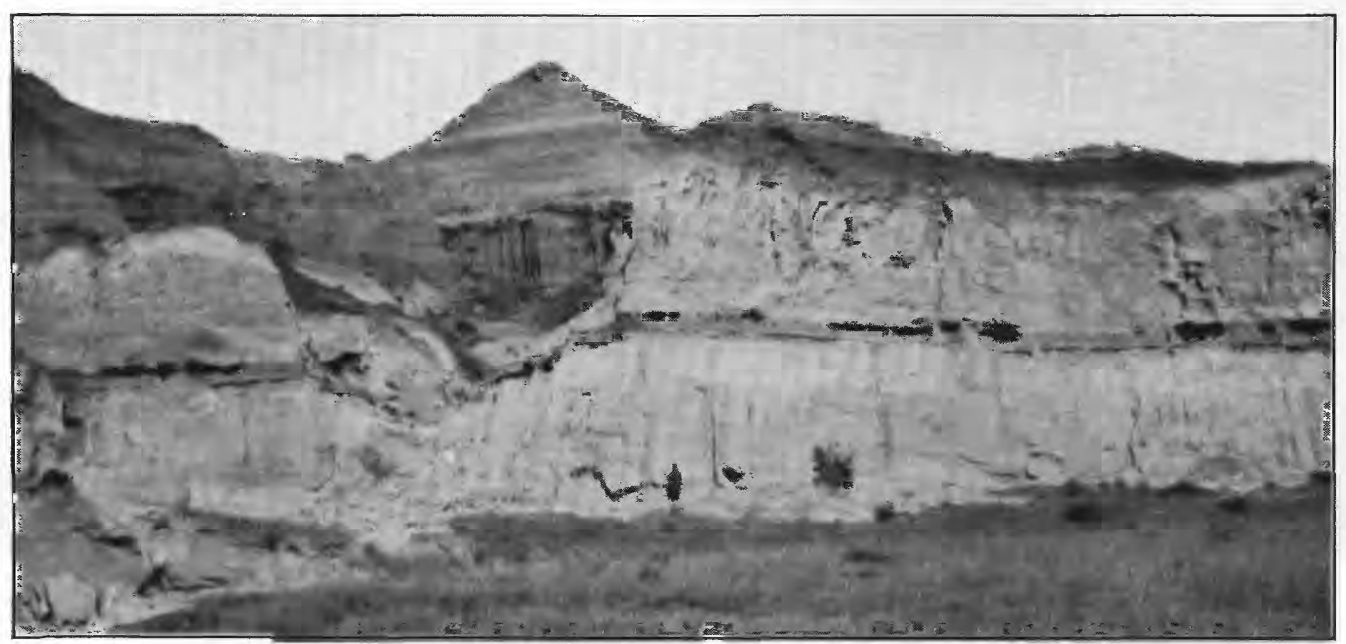

C. COLGATE SANDSTONE 4 MILES SOUTHWEST OF GLENDIVE, MONT. 
Section in the Fox Hills and Lance formations on Little Beaver Creek in the SE. 1/4 sec. 7, T. 132 N., R. 106 W., N. Dak.

[See pl. 5, A]

Lance formation (lower part):

Sandstone, light yellowish brown, coarse grained; contains scattered fragments of carbonized wood.-

Sandstone, yellowish brown, soft, cross-bedded, medium grained; contains large copper-colored ooncretionary masses that are hard and weather out unbroken . . . . . .

Sandstone, shaly, and sandy shale, light gray to drab, soft; contains thin crusts of limonitic material and small limonitic concretions; cross-bedded.........

Sandstone, rust-colored, coarse grained, mueh crossbedded; contains many siderite concretions; at some places hard, at others, soft .................

Sandstone, soft, light gray; contains rust-colored, iron-stained masses that are hard and contain many

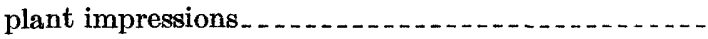

Shale, sandy, and shaly sandstone, brown, carbo-

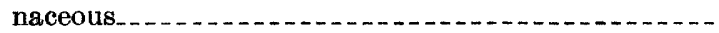

Shale, black, carbonaceous ..........................

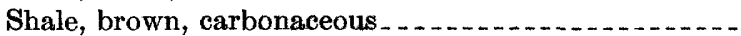

Sandstone, gray white, shaly, coarse grained, crossbedded locally but otherwise massive ... . . . . . . . . .

Shale, brown, carbonaceous, irregular... . . . . . .

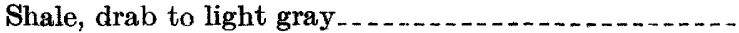

Fox Hills formation:

Colgate sandstone member (part) -

Sandstone, light gray, soft; contains many fossil roots of plants.

Shale, drab to light gray, with very irregular base - .

Sandstone, gray-white, and gray shale, very much cross-bedded and irregular

Sandstone, gray-white, massive to rather indistinctly bedded, shaly in places; lower 10 feet streaked with iron stains; locally contains irregular thin lenses of carbonaceous shale. Halymenites major throughout. Forms the smooth wall above creek level shown in Plate 5, $A_{\ldots} \ldots$...

\section{Creek level.}

Shale, carbonaceous.

In the railroad cut $31 / 2$ miles west of Marmarth the Colgate sandstone is about 30 feet thick, massive, locally cross-bedded, and overlain by a carbonaceous shale bed 1 foot thick. (See pl. 4,C.) About 5 miles south of Marmarth, in the NE. $1 / 4$ sec. $32, \mathrm{~T} .132 \mathrm{~N}$., R. $106 \mathrm{~W}$., the Colgate is again well exposed and contains abundant remains of Halymenites major. Other details regarding the Fox Hills and Lance formations in the Marmarth area are given by Stanton, ${ }^{20}$ with whose conclusions the writers coneur-that "it is most probable that the abrupt change from marine to fresh-water and land conditions seen near Marmarth is purely local and that the eroded surface

20 Stanton, T. W., Fox Hills sandstone and Lance formation ("Cerctops beds") in South Dakota, North Dakota, and eastern Wyoming: Am. Jour. Sci, 4th ser., vol. 30, pp. 182-184, 1910.

$33225^{\circ}-29-2$ at the top of the Fox Hall does not represent a time interval of any geologie importance."

\section{MARMAMFr, N. DAK, TO GLRMDIVE, MONT.}

In the SW. $1 / 4$ sec. 34, T. 7 N., R. 61 W., Mont., about 1 mile west of the North Dakota line, the Colgate sandstone displays a elean-cut contact with the overlying horizontal Lance beds. The sandstone is crossbedded and channeled on a small scale, but the significance of the uneonformity is minimized by the fact that at short distances away the contact is not sharp nor discordant.

Other unconformities betwen the Fox Hills and Lance formations, reported by Knowlton ${ }^{21}$ on the authority of Calvert to occur in sec. $22, T .6 \mathrm{~N}$, R. 60 E., and sec. 32 , T. 7 N., R. 61 E., Montana, vere not found in these sections. The writers examined every outcrop along the, contact in T. $7 \mathrm{~N}$. but could find no evidence of unconformity other than crossbedding and purely local chaineling of a kind present at many levels in both Fox' Hills and Lance. 'As Knowlton was quoting Calvert, who supervised the mapping of the area by Bowen, ${ }^{22}$ it is possible that a mistake was made somewhere in the process of handing on the references and that it was intended to cite the localities as in sees. 27 and 32, T. 6 N., R. $60 \mathrm{E}$., as said elsewhere by Calvert, though Bowen's map shows no Colgate in sec. 32, T. 6 N., R. 60 E. Sec. 32 , T. 7 N., R. 61 E., is on the east side of the Cedar Creek anticline and not on the west side, as said by Knowlton. Published photographs ${ }^{24}$ of one of these unconformities show local channeling and cross-bedding, such as characterize the upper part of the Fox Hills throughout its extent.

It has been stated that the Fox Hills and Lance are unconformable along the Cedar Creek anticline because in the Baker field the Colgate sandstone, which at the time the statement was made was considered a men ber of the Lance, "appears to rest directly on Pierre shale without the interyention of the lower strata so noticeable at Iron Bluff" (near Glendive). ${ }^{25}$ The writers" examinations along the whole length of the antipline have convinced them that the basal brown sandstone of the Fox Hills is present throughout the greatar pact of the anticline, though it is replaced by gray sandy strale in a few localities, and that the upper white sands $*$ no contains Hatymenites at many place and is marin?.

21 Knowiton, F. H., Further data on the stratigraphic position of the Lan' formation ("Ceratops beds"): Jour. Geology, vol. 19, p. 366, figs. 2,3 , 1011 .

${ }^{22}$ Bowen, C. F., The Baker ligni feld, Custer Colanty, Mont.: U. 8. Geol. Survey Bull. 471, pp. 202-276, 1912.

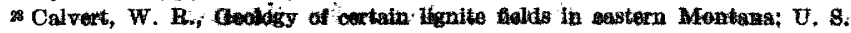
Geol. Survey Bull. 47, 195, 1912:

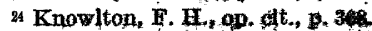

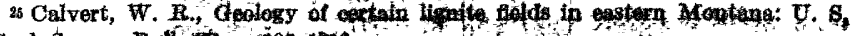
Geol. Survey Buth, p. 10, 1912 
The rocks near Glendive were first studied by Leonard, ${ }^{26}$ who says:

In the Glendive region there are no beds above the marine Pierre that correspond to the supposed Fox Hills clay and sandstone of Hell Creek. In fact, the line of contact between the Pierre and the overlying dinosaur-bearing beds, while not discordant so far as structure is concerned, may possibly represent a time break in which most of the upper fresh and brackish water beds of the Cretaceous are wanting.

It may be seen from this statement that all the rocks above the Pierre shale were included by Leonard in the dinosaur-bearing beds, the Lance formation. Leonard's section is as follows:
35 feet thick is 150 feet stratigraphieally above Fierre shale. In the Baker field, however, this wbite sandstone, which Leonard states constitutes the most prominent stretum in the region, appears to rest directly on Pierre shale vithout the intervention of the lower strata so noticeable at Iron Bluff.

Observations made by the writers at Iron Bluff and vicinity show that the section published by Leonard and quoted by Calvert is in error. It was assumed by Leonard that the sandstone (No. 3 of Leor ard's section) capping Iron Bluff (see fig. 4) dips eastward beneath the Colgate sandstone in the bluffs east of Sand Creek. It is clear, however, that the Colgate is present in Iron Bluff beneath the top of Leonard's No.

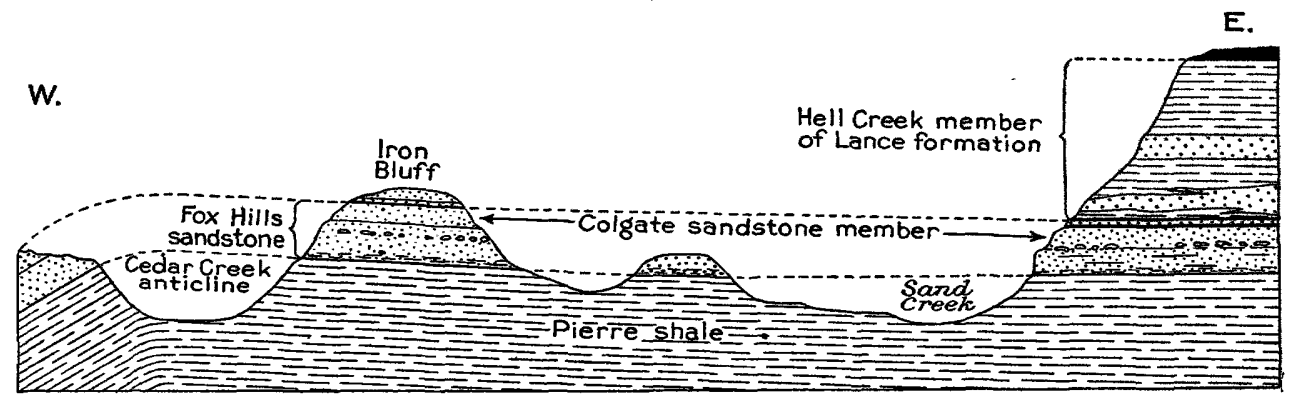

Frgure 4.-Diagrammatic cross section across the Cedar Creek anticline at Iron Bluff, near Glendive, Mont.

Section of rocks at Iron Bluff and vicinity

8. Coal bed, burned but probably 6 feet thick.

7. Shale with a few thin beds of sandstone; abundant collection of fossil plants in sandstone bed 20 feet from

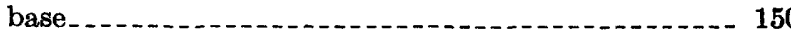

6. Sandstone, massive, gray

5. Shale and sandstone; $a$ few fossil plants at base...... 160

4. Sandstone, white, massive; most prominent stratum in the region.

3. Sandstone, brown; fossil leaves in bottom part; forms summit of Iron Bluff.

1. Shale, dark, Pierre, with limestone concretions containing abundant marine fossils; exposed to river level_.- 100

635

Calvert ${ }^{27}$ later grouped Nos. 2, 3, and 4 of Leonard's section into the Colgate sandstone member of the Lance formation and wrote:

Although there is in the Iron Bluff section an appearance of transition from the Pierre shale into the overlying arenaceous strata, which suggests that the sandstone occupies ${ }^{-1}$ the stratigraphic position of the Fox Hills, the evidence of fossil leaves indicates that much if not all of it is of later age.

Referring to the finding in units 2 and 3 of fossil plants that were identified by Knowlton as Tertiary species, he says:

It is certain that if the Fox Hills sandstone is present in this section it is restricted to the 70-foot interval between the location of the fossil plants and the top of the Pierre shale. * * * Southward from Iron Bluff the stratigraphy suggests even more strongly that the Fox Hills is not present. In the section near Iron Bluff, as given by Leonard, a white sandstone

26 Leonard, A. G., The coal fields of parts of Dawson, Rosebud, and Custer Counties, Mont.: U. S. Geol. Survey Bull. 316, pp. 197-198, 1907.

${ }^{27}$ Calvert, W. R., Geology of certain lignite fields in eastern Montans: U. S. Creol. Survey Bull. 471, pp. 194-196, 1910.
3 , as shown in the section on the east face of Iron Bluff given below. (See also fig. 4.) On the north face of Iron Bluff the Colgate is much discolored by brown ferruginous stain leached from the overlying rust-brown sandstone, a lens in the basal Lance which does not seem to extend eastward across Send Creek. On Sand Creek the upper part of the lower nember of the Fox Hills yielded marine fossils.

In summary, it may be said that near Glendive the Fox Hills sandstone maintains all the charqcteristics observed farther east, except that the Colgate memiber contains well-preserved fossil plants, which have been identified by Knowlton as Fort Union (Tertiary) species. ${ }^{28}$

As shown in Plate 5, $B$, beds of lignite also occur in the Colgate member and in the Hell Creel: member, immediately above. Sections at Iron Bluff and Sand Creek are as follows:

Section of the Fox Hills and Lance formations at Iron Bluff, southwest of Glendive, Mont.

Lance formation (part of Hell Creek member or "somber "Feet

beds"):

Sandstone, brown, platy; makes top of Iron Bluff _... 4

Concealed, probably like unit above............... 20

Sandstone, light gray with rusty stain locally, fairly cross-bedded . - ... . . . -

Concealed, probably sandstone

Fox Hills sandstone:

Colgate sandstone member-Sandstone, white, fine grained, massive; deeply stained at places by material leached from the overlying ferruginous sandstone

28 Calvert, W. R., Geology of certain lignite fields in eastern Montana: U. S Geol. Survey Bull. 471, p. 195, 1912. 
Fox Hills sandstone-Continued. Lower member-

Sandstone, brown, containing many ferruginous nodules..............

Sandstone, soft, yellow, containing discontinuous layers of dark-brown platy sandstone.......... Sandstone, soft, yellow .......................... Sandstone, light gray, fine grained, concretionary Sandstone, soft, yellow ......................... Sandstone, dark brown, platy and concretionary Sandstone, dark colored, soft; weathers yellow .. Sandstone, soft, shaly, light gray; weathers

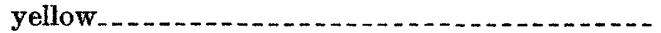
Shale, sandy, gray, stained with limonite......

Shale, brown and gray, sandy

Total lower member . . . . .

Pierre shale: Shale, gray, sandy, with many large fossiliferous concretions in upper 20 feet.

Section of the Fox Hills sandstone on east side of Sand Creek, 4 miles southwest of Glendive, Mont.

Lance formation (Hell Creek member or "somber beds"). Fox Hills sandstone:

Colgate sandstone member-

Sandstone, white, fine grained, massive, sugary; crops out in a prominent white bluff and contains many well-preserved fossil plants identified as Fort Union (Tertiary) species............

Coal, impure . . . . .

Sandstone, like that above

Total Colgate member.

Lower member-

Sandstone, coneretionary, lenticular..............

Sandstone, brown, limonitic, slabby, grading upward into soft yellow shaly sandstone and sandy shale; contains Vanikoro ambigua, Fusus dakotensis, and Anomia? sp. 15 feet below top...

Total lower member.

Pierre shale.

\section{NORTHEASTERN MONTANA}

In western and northwestern Garfield County, Mont., the lower member of the Fox Hills consists of a massive yellow-brown coarse-grained sandstone that averages about 75 feet in thickness and makes a prominent wall along the tributaries to the Musselshell and Missouri Rivers. The white Colgate member overhes the lower member and can be seen for miles as its outcrop meanders in and out of numerous coulees. (See pl. 5, C.) The lower member is marine in this region, but no fossils were found in the Colgate nember. East of Hell Creek the white Colgate member is replaced by friable yellow to brownish sandstone and sandy shale.

Channeling and cross-bedding are common in the Colgate member in this region, but during detailed mapping by Mr. Dobbin, extending over two field seasons, no evidence was found to indicate a major break at the top of the Fox Hills. This conclusion is in accord with the findings of Brown, ${ }^{29}$ who says:

* Brown, Barnum, Cretasons-Eocene correlation in New Mexico, Wyoming, Montana, Alberta: Geol. Soc. America Bull., vol. 25, pp. 357-358; 1914.
On the east fork of Crooked Creak near the old Cook ranch, on the west fork of Crooked Creek near the Gus Colin cl $\varepsilon^{i} m$, and on the east fork of Hell Creek near the EE cattle camp, these marine beds (Fox Hills) have been eroded in places, sometimes to a depth of 10 feet, before the succeeding massive se ndstones of the fresh-water "Lance" were deposited. The strata are, however, in all cases parallel to the bedding plane of the succeeding sandistones, and the break is evidently of local erosional character. * * * No sign of an angular unconformity has been noted between the Fox Hills and the "Lanse," and I have never yet any geologic evidence of the "grat diastrophic break" which is alleged to oceur here. $\rightarrow$

The following section is typical of the Fox $\mathrm{F}^{-i}$ lls sandstone along the Musselshell and Missouri Riras in Garfield County:

Section of Fox Hills sandstone on Devil Creek, in the SE. 1/4 sec. 16, T. 21 N., R. \$2 R., Mont.

Lance formation (Hell Creek member or "somber beds).", Fox Hills sandstone:

Colgate sandstone member: Sandstone, white, fine grained, massive

Lower member:

Shale, yellow, sandy, with thin beds of sandstone.- 11

Sandstone, concretionary .................... 1 Sandstone, brown, hard; makes a ledge; contains Lingula nitida Meek and Hayden in abundance_ 2 Shale, yellow, sandy ........................ 5 Sandstone, yellow, fairly hard; makes a wall.... 15 Sandstone, brownish yellow . . . . . . . . . . . . 15 Shale, gray, sandy ..................... 4 Sandstone, yellow, soft, shaly at base_.......... 20

Total Fox Hills sandstone................... 103 Bearpaw shale (=upper Pierre).

In T. 16 N., R. 38 E., Montana, about 69 miles north of Forsyth, Bauer ${ }^{30}$ found quartzite and Forphyry pebbles at a horizon considered by him the $\mathrm{k}$ qse of the Lance formation. The pebbles are half an inch to 3 inches or more in diameter and are embedded in impure limonite, which ranges in thickness from 3 in 8 inches. A detailed examination of this loeality by $\mathrm{Mr}$. Dobbin has shown that the conglomerate is confommable with the underlying beds in most of the exposures, though locally there are indications of channeling such as characterize the upper part of the Fox Hills throumhout its extent. As the conglomerate occurs pnly in this small area, its presence affords little proot of the existence of a major unconformity at the contact of the Fox Hills and the Lance.

The relations between the Fox Hills and Lance formations in the region between the Missouri River and the Canadian boundary can not be satisfactorily determined, owing to the covering of late $\mathrm{Ter}$ tiary and Pleistocene deposits: Studies by $\$$ mith, ${ }^{31}$

so Bauer, C. M., Quartzite pebbles at the base of the Lance formation if Mon toner Am. Assoc. Petroleum Geologtsts Buld, vol. 9, pp. 344-346, 1925.

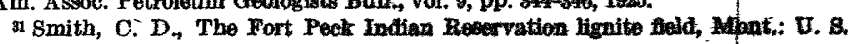
Geol. Survey Bull. 381, p. 42, 1910. 
Beekly, ${ }^{32}$ and Collier ${ }^{33}$ indicate that the beds tentatively called Fox Hills in this region are probably of continental origin, as shown by the lack of marine fossils and by the finding of remains of a trachodont dinosaur in a sandstone "which surely lies only a short distance above the Bearpaw" (= upper Pierre). ${ }^{34}$ These remains were identified as belonging to the species Trachodon annectens Marsh, a form which also occurs in the Lance of the Hell Creek area. This occurrence is noteworthy in view of the fact that the Fox Hills contains marine fossils on the south bank of the Missouri River and also in Canada, only a few miles from the locality where the dinosaur remains were found. ${ }^{35}$ Studies by McConnell ${ }^{36}$ indicate that the Fox Hills and "Laramie" (Lance) are conformable also in the Cypress Hills, which lie but a short distance northwest of the Wood Mountain Plateau.

\section{central hontana}

West and southwest of Forsyth, Mont., the Bearpaw shale (= upper Pierre) is conformably overlain by nonmarine sandy shale and sandstone, locally indistinguishable from the rest of the Lance formation. These beds are indubitably of fluviatile origin, yield characteristic Lance fresh-water invertebrates, and probably represent the purely continental phase of the marine Fox Hills of the Dakotas.

\section{SOUTHEASTERN MONTANA}

The Fox Hills formation in the southeast corner of Montana is similar to the outcrops near Marmarth, N. Dak., except that locally the white Colgate member is replaced by brown sandstone. Near Ridge the Colgate member is more resistant than in areas to the north and east and makes bluffs 60 feet high. Excellent exposures at certain localities in this area fail to show any evidence of an unconformity between the Fox Hills and Lance.

\section{RIDGE, MONT., TO LANCE CREEK, WYO.}

Between the Montana-Wyoming State line and Moorcroft, Wyo., the contact of the Fox Hills and Lance could not be studied in detail, because of the lack of exposures in areas of low relief. The lower part of the Fox Hills in this area consists of brown slabby marine sandstone and sandy shale, which crop out in a pronounced escarpment that stands well

\footnotetext{
32 Beekly, A. L., The Culbertson lignite field, Valley County, Mont.: U. S. Geol. Survey Bull. 471, pp. 329-330, 1912.

${ }^{33}$ Collier, A. J., Geology of northeastern Montana: U. S. Geol. Survey Prof. Paper 120, pp. 30-31, 1919.

a Collier, A. J., op. cit., p. 31.

ss Rose, Bruce, Wood Mountain coal area, Saskatchewan: Canada Geol. Survey Summary Rept. for 1914, p. 65, 1915.

86 MeConnell, R. G., Report on the Cypress Bills, Wood Mountain, and adjacent country: Canada Geol. Survey Ann. Rept., new ser., vol. 1, pt. C, p. 26 c, 1885.
}

above the Pierre lowlands to the east. Rubey ${ }^{37}$ has mapped this area in detail and reports that the Colgate sandstone member of the Fox Hills is either absent or present as some other lithologic facies-for example, a brown unconsolidated sandstone that oeenrs locally between the marine Fox Hills and the Triceratopsbearing Lance beds may be equivalent to $t^{\text {he }}$ Colgate sandstone member.

On Good Lad Creek, less than a quarter of a mile below Oshoto post office, in the SW. $1 / 4$ sec. 7, T. 53 N., R. $67 \mathrm{~W}$., Wyoming, sandy beds that are possibly of Fox Hills age stand vertical in a cut bank, and 400 feet upstream, directly opposite Oshoto post office, beds of brown and gray sandstone containing prominent concretions, such as characterize the Lance, dip about $5^{\circ} \mathrm{SW}$. The great decrease in dip within so short a horizontal distance has been throught by some to indicate a structural unconformity between the Lance and Fox Hills. An examination of the locality by the writers showed that the exposures are tco poor to reveal the structure with certainty. It is believed, however, that the abrupt change in dip is due either to sharp unsymmetrical folding or to folding and faulting on a prominent monocline, which has been mapped by Rubey ${ }^{37}$ for a distance of 30 miles.

In the same area as that described in the preceding paragraph Darton and O'Harra ${ }^{38}$ reportet the Fox Hills to be apparently 400 to 450 feet thick and to contain vertebrate bones, fossil wood, and species of Inoceramus. That the record of Inoceramus was due to a misidentification of Unio couesi which crused these writers to include a portion of the Lance containing this fossil in the Fox Hills sandstone has been proved by a subsequent examination of the precise locality described. The true thickness is much less than that reported.

At 4 miles southeast of Moorcroft the Fox Hills sandstone is well exposed in a conspicuour ridge but affords no evidence of an unconformity with the Lance. The Fox Hills is about 200 feet thick at th is locality.

The Fox Hills is also well exposed in the escarpment 7 miles northwest of Upton, Wyo. Its top is a white sugary sandstone overlain by a bed of purple carbonaceous shale. The white sandstone contains Halymenites, major and is possibly a correlative of the Colgate sandstone of southeastern Montana, though this can not be proved. Dinosaur bones were col scted from the Lance beds less than 50 feet above the purple carbonaceous shale, and marine fossils wer? obtained in the lower member of the Fox Hills.

About 13 miles west of Newcastle the Fox Hills and Lance exhibit the following section:

37 Rubey, W. W., personal communieation.

39 Darton, N. H., and O'Harra, C. C., U. S. Geol. Survey Gesl. Atlas, Devils Tower folio (No. 150), p. 5, 1907. 
Section 13 miles west of Newcastle, Wyo.

Lance formation (part):

Sandstone, yellow-brown, containing flat hard brown sandstone concretions; unit weathers into "toadstools"

"Somber shale," composed of dark-gray sandy clay with small botryoidal masses of limonitic sand, brown concretions, and a little hard sandstone in thin layers; turtle and dinosaur bones at top....

Slope probably underlain by gray sandy clay shale.

Sandstone, soft, light gray, and shale, dark gray, alternating in thin layers; contains a little hard brown platy sandstone; no fossils noted, assignment arbitrary

Fox Hills sandstone:

Sandstone, hard, platy, dark brown; forms cap rock of many small buttes.

Sandstone, rather soft, yellow to light gray; weathers to a slope

Sandstone, argillaceous, very soft, slope forming; contains a few somewhat harder layers, some thin layers, and a few concretions of siderite. At 44 feet above base (U. S. G. S. locality 12833) contains Crenella elegantula Meek and Hayden, Veniella humilis Meek and Hayden, Pyrifusus newberryi Meek and Hayden, Haminea sp.; at 5 feet above base (U. S. G. S. locality 12832), Serpula? sp., Nucula sp., Yoldia evansi Meek and Hayden, Pecten nebrascensis Meek and Hayden, Anomia gryphorhynchus Meek and Hayden, Modiola meeki Meek and Hayden, Crenella elegantula Meek and Hayden, Crassatellites subquadratus Whitfield?, Lunatia concinna Hall and Meek, Anchura americana Evans and Shumard. Pyrifusus newberryi Meek and Hayden, Fasciolaria culbertsoni Hall and Meek, Cinulia concinna Hall and Meek, Baculites ovatus Say, and undetermined fish scales.

Total Fox Hills sandstone.

Pierre shale:

Limestone concretions, gray, 3 to 4 feet in diameter, most of them septarian and without fossils; Baculites ovatus Say, B. compressus Say, Yoldia evansi Meek and Hayden seen

Shale, greenish gray, sandy, with a few small calcareous concretions... . . . . . . . . . . . .

Concealed under a grassy flat, probably in part large sandy gray shale; extends eastward from Fox Hills escarpment. About a mile east of the Fox Hills escarpment (U. S. G. S. locality 12757) contains Nucula sp., Yoldia evansi Meek and Hayden, Cucullaea shumardi Meek and Hayden, Gervillia subtortuosa Meek and Hayden, Inoceramus fibrosus (Meek), Inoceramus sagensis Owen, Pteria nebrascana Evans and Shumard, Ostrea sp., Pecten nebrascensis Meek and Hayden, Syncyclonema halli Gabb, Anomia gryphorhynchus Meek and Hayden, Modiola meeki Evans and Shumard, Crenella elegantula Meek and Hayden, Cuspidaria sp., Lucina sp., Protocardia subquadrata Evans and Shumard, $P$. borealis Whiteaves, Corbula cf. C. crassimarginata Meek and Hayden, Dentalium gracile Meek and Hayden, Lunatia occidentalis Meek and Hayden, Anchura sp., Haminea subcylindrica Meek and Hayden, Baculites ovatus Say, B. grandis Hall and Meek, Discoscaphites nicolleti Morton, D. abyssinus Morton, and $D$. conradi Morton var.
The Fox Hills sandstone has been reported, ${ }^{40}$ on the authority of D. E. Winchester and V. H. Barnett, to . be 1,040 feet thick on Alkali Creek, on the same line, of outerop as the much thinner sections reported nar Newcastle and Moorcroft. This greater thickness has been interpreted as normal for the formation and the smaller thicknesses found elsewhere as representing only a remnant left by pre-Lance erosion. ${ }^{41}$ The grat thickness reported is, however, incorrect, as shown by the detailed section measured by the writers and giren below. The Fox Hills on Alkali Creek is thicker, it is true, than at the more northerly localities, but it reaches only the moderate thickness of 357 feet and is transitional into the overlying Lance, as described by

3 Brown. ${ }^{42}$ Stanton's section at the mouth of Lance Creek, ${ }^{43}$ some miles south of Alkali Creek, agrees vell with that measured by the writers, though it is somewhat thicker-about 400 feet.

Section measured in sec. 18, T. $40 \mathrm{~N}, \mathrm{R} .61 \mathrm{~W}$. and secs. 11 and 13, T. 40 N., R. 62 W., Wyo., between Alkali Creek and Robbers Roost Creek

Lance formation (part):

Shale, somber colored; contains abundant remains of

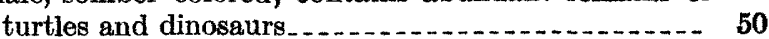

Shale, carbonaceous, and coal ...

Fox Hills formation:

Sandstone, brown, concretionary; contains abundant remains of dinosaurs, crocodiles, and turtles near top. V. H. Barnett and D. E. Winchester "reported marine fossils at a horizon 35 feet below top of this unit. The present writers did not succeed in verifying their report. This unit may belong in the Lance-.....

Sandstone, gray, filled with shells of Corbieula ef. $C$.
subelliptica Meek and Hayden; a brackish-water deposit that may belong to the Lance.............

Sandstone, gray, and soft sandy shale, inseparable in

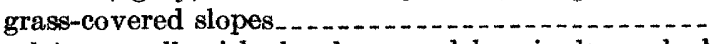

Sandstone, yellowish, hard, capped by ripple-marked fissile concretions; contains Yoldia evansi Meek and Hayden, Crenella? sp., and Haminea minor Meek in basal part (U. S. G. S. locality 12586) _...........

Shale, dark gray, and sandstone, soft, light gray, interlaminated; contains botryoidal masses of limonite and concretions of platy brown sandstone; mass weathers into slopes like the Lance "somber beds"; contains Nucula sp. indet., Modiola attenuata Meek and Hayden, Cardium speciosum Meek and Hayden, Tellina sp. indet.; 25 feet below top (U. S. G. S. locality 12585) _...

Sandstone, platy, hard, brown

Clay, somber-colored. Concealed; probably interlaminated gray and brown
sandy shale and sandstone much like third unit above

${ }^{40}$ Calvert, W. R., and others, Geology of the Standing Rock and Cheyenne Fiver Indian Reservations, North and South Dakota: U. S. Geol. Survey Bull. 575, p. $12,1914$.

${ }^{41}$ Knowlton, F, H., Cretaceous-Tertiary boundary in the Rocky Moustain region: Geol. Soc. Americe Bull., vol. 25, pp. 326-327, 1914.

42 Brown, Barnum, Cretaceous-Eocene correlation in New Mexico, Wyoring, Mantana, Alberta: Geol. Soe. America Bull., vol. 23, p. 358, 1814.

43 Stanton, T. W, Fox Hills sandstone and Lance formation ("Cerotops be is)" in South Dakota, North Dakota, and eastern Wyoming: Am. Jour. Bei., 4th ser., vol, 30, pp. 184-185, 1910.

44 Unpublished data. 
Fox Hills formation-Continued. Sandstone, gray, platy; makes bench

Sandstone, brown, limonitic, hard and platy; makes the cap rock on the lowest Fox Hills escarpment... Sandstone, yellow, massive, soft; contains large hard brown calcareous concretions, which yielded (U. S. G. S. locality 12584) Membranipora n. sp., Gervillia subtortuosa Meek and Hayden, Inoceramus (Actinoceramus) fibrosus Meek and Hayden, Veniella humilis Meek and Hayden, Protocardia subquadrata Evans and Shumard, Tellina equilateralis Meek and Hayden, Dentalium gracile Meek and Hayden, Fasciolaria cheyennensis Meek and Hayden?, Fasciolaria galpinianum Meek and Hayden, Cinulia concinna Hall and Meek, Discoscaphites nicolleti (Morton), Sphenodiscus lenticularis (Owen), Hypsodon sp., and Centrarchites? sp..................... Sandstone, gray, shaly but hard enough to make a prominent bench. . . . . . . .

Total Fox Hills.

Pierre shale.

In the upper Lance Creek area the Fox Hills is about 500 feet thick and is transitional into the Lance. Winchester ${ }^{45}$ reports a thickness of 748 feet, but examination by others has not substantiated so great a thickness as this. An increase in thickness toward the southwest has been established for all the marine formations of the Montana group and for the overlying Lance and Fort Union formations and is possibly due to the fact that the chief source of the sediments lay toward the southwest. Practically all sections of the Fox Hills in this particular area contain several beds of massive white sandstone, some of which are associated with beds of coal and impure shale. The following section, given by Stanton, ${ }^{46}$ is typical of the Fox Hills in this area:

Section on Johnson Bros.' ranch near Buck Creek

Lance formation: Sandy shale with thin beds of coal_.... 25 Fox Hills sandstone:

Massive white sandstone with Halymenites major _... 60

Yellowish massive sandstone with brown concretions_ 20

More thinly bedded brown sandstone with Halymenites 25

Massive white sandstone ............................ 75

Soft, somewhat sondy shales with thin sandstone

bands containing marine Fox Hills shells.......... 30

Brown shaly sandstone.

Massive white sandstone..................... 60

Thin-bedded brown and gray sandstone............. 130

Yellowish massive sandstone with concretions contain-

ing Fox Hills fauna . . . . . . 100

Pierre shale.

Total Fox Hills

$\overline{505}$

CENTRAL WYOMING

In the district near the Salt Creek oil field the freshwater Lance formation is 3,200 feet thick and is

\footnotetext{
is Winchester, D. E., The Lost Spring coal field, Converse County, Wyo.: U. \$. Ged. Survey Bull. 471, p. 478, 1912.

46 Stanton, T. W., Fox Hills sandstone and Lance formation ("Ceratops beds") in South Dakota, North Dakoten and eastern Wyoming: Am. Jour. Sci., 4th ser.,
} vot. 30, p. 186, 1910 . underlain conformably by a series of beds designated the Lewis shale. The uppermost part of the Lewis. is a pure-white sandstone 100 to 150 feet trink which bears Halymenites and is possibly a correlative of the Colgate sandstone of eastern Montana. Shate associated with the white sandstone contains Fox Hills fossils, ${ }^{47}$ and the sandstone itself contains ond or more coal beds, generally only a few inches thin but in some places as much as 5 feet thick. The bets through an interval of 600 feet below the white sandstone are predominantly sandy, though in at least $r$ alf of this interval they contain distinctive Pierre fosgils and are equivalent to the uppermost part of the Pierre shale of eastern Wyoming. Deposition of sendy beds, therefore, began earlier here than it did farther east. There are only arbitrary boundaries between representatives of the Pierre, Fox Hills, and Lance.

At Glenrock, east of Casper, the uppermist part of the Lewis shale, just under the Glenrock coal bed of the Lance, is a massive pure-white sandstone about 75 feet thick that contains Halymenites throughout. Under it lies perhaps 125 feet of yellow-brown massive sandstone containing many concretions of red-brown hard calcareous sandstone. Beneath this yellowbrown sandstone lies about 125 feet of shale, thinbedded sandstone, and coal, beneath which in turn is a second yellow sandstone 70 feet thick. Barnett ${ }^{48}$ reports the beds above the coal-bearing zone as 100 feet thick, but this figure is not quite larme enough. Beneath the rocks above described, which are very likely of Fox Hills age, lie some 600 feet of interbedded sandstone and shale and, still lower, less s`ndy beds. These all contain a Pierre fauna and ari therefore. older than the Fox Hills.

In the Poison Spider district, 35 miles west of Casper, the Lewis shale is about 800 leot thick $a+d$ consists of alternating beds of sandstone, shale, carbonaceous shale, and coal; the upper beds contain a distinctive Fox Fills found with Sphenodiscus, ete, and the lower beds an upper Pietre fauna. There are alternations of marine and nonmarine beds, and the entire section can be interpreted only showing a gradual change from marine to continental conditions. A section illustrative of this district follows:

Section at the center of T. $39 N ., R .83$ W., Wyo., 3 willes southwest. of the Poison Spider oil field

Lance formation (basal part): Shale, sandy, grey, with carbonaceous shale, thin coal beds, and concritionary sandstone; forms a prominent scarp. This unit is the lower part of the ceal-bearing zone of the Lance formation. . . . . . . .

47 Wegemann, C. H, The Susser conl neld, Johnson, Natrorn, and Converse Counties, Wyo.: U. S. Ged. Survey Eull. 471, p. 445, 912; The Salt Creek oil fleld, Wyo.: U. S. Geol. Survey Bull. 670, p. 23, 1918 .

48 Barnett, V. H., Possibilities of oil in the Big Muddy dorre, Converse and Natrona Counties, Wyo.: U. S. Geol. Survey Bull. 581, p. 114, 19:5. 
Lewis shale:

Sandstone, yellow, caleareous, cpncretionary'; breaks into irregular pieces and contains Halymenites..... Sandstone, gray-white, soft . . . Shale, gray to brown, sandy

Sandstone, brown, concretionary, limy; contains fossil plants in upper part (U. S. G. S. locality 7508), including Taxodium occidentale Newberry, Ficus cockérelli Knowlton?, Rhamnus salicifolius Lesquereux?, and Ficus sp.; also Ostrea glabra Meek and Hayden in lower 6 inches (U. S. G. S. locality 10708) .......

Shale, sändy, gray; contains thin lenses of papery sandstone. . . . .

Shale, brown, sandy, grading upward into a prominent concretionary sandstone that contains a Fox Hills fauna, including Nucula sp., Glycimeris wyomingensis (Meek), Pteria linguaeformis Evans and Shumard, Pteria nebrascana Evens and Shumard, Ostrea cf. $O$. glabra Meek and Hayden, Tancredia americana? Meek and Hayden, Cardium spéciosum Mreek and Hayden, Callista nebrascensis Meek and Hayden, Tellina scitula Meek and Hayden, Turritella sp. undescribed, Pyrifusus newberryi Meek and Hayden, Sphenodiscus lenticulare (Owen) (U. S. G. S. locality 10707)

Shale, gray, sandy

Sandstone,

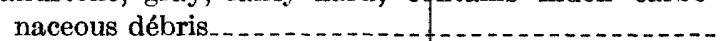

Shale, gray, sandy

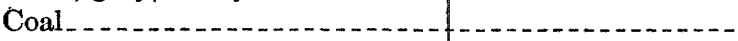

Shale, sandy, grayish white; contains thin lênsies of yellow concretionary sandstone.

Sandstone, gray, platy, concretionary

Shale, sandy, gray and brown, soft.

Shàle, gray, and carbonaceous shale, sandy shàle, and concretionary sandstone; appears to be nonmarine.

Sandstone, brown, haird; mäkès a smàill rídge . . . . .

Shale, gray, carbonaceous.....................

Sandstone, soft, carbonaceous; contains several hard layers . .

Shale, sandy, gray and brown . . . . .

Shale, some sandy and some carbonaceous..........

Saridstone, gray, carbonaceous . . . . . . . . . . . . . . .

Sandstone, white; contains many gray cannon-balt concretions as much as 3 feet in diameter............

Shale, sandy, brown; occupies a low valley .........

Sandstone, gray and brown, with many large darkbrown concretions; contains in upper part $a$ large Pierre fauna including Baculites compóréses Say, B. ovatus var. baculus Meek, and Scaphites nodosus Owen (U. S. G. S. localities 10705, 10706) ........

Shale, gray, marine, sandy, grading upward into overlying brown sandstone; Baculites compressus Say (U. S. G. S. locality 10709) $-200$

Mesaverde formátion: Téapot sandstone hogback.

\section{SOUTHERN WYOUIING}

In southern Wyoming the marine Lewis shale is succeeded by beds formerly called the Laramie formation but now designated "Laramie" or Medicine Bow formation. There is complete transition from marine to nonmarine deposits, and the transition beds are generally assigned to the succeeding formation because they are sandy and hence more like it in lithology than the underlying Lewis shale.
About 10 miles west of Rawlins, just north of $B+n$ station on the Union Pacific Railroad, good expost of Lewis and overlying beds show the transition from marine to nonmarine beds through strata that are undoubtedly of Fox Hills age but here, as in the Casper region, are not separable except arbitrarily from the beds above and below. The following section illustrates the sequence:

\section{Section 10 miles west of Ravilins, Wyo.}

aramie" formation (part):

Shale, sandy, brown, with thin carbonaceots shale beds and concretionary sandstome; contain Unie priscus Meek and Hayden, Compeloma muttilineatio Meek and Hayden, Tulotoma thompsoni White, and Goniobasis tenuicarinata Meek and Hayden 140 feet .below top (U. S. G. S. locality 12507); Unio priseus Meek and Hayden 165 feet below top (U. S. G. S. locality 12507); and Unio holmesianus White 40 feet above base (U. S. G. S. locality 12505) . . . .... 28

Sandstone, brown

Shale, sandy, brown, with a few coneretionary sandstone lenses. Fragment of undeterminable dinosaur bone 85 feet below top; ceratopsian remains 300 feet below top.

Sandstone, brown, concretionary; contains many Halymenites; highest marime horizon noted....... Shale, brown, sandy, with thin platy sandstone......

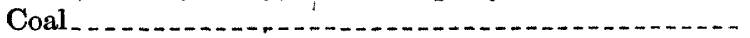

Sandstone, brown, concretiofiary; gray sandy shale; and severat carbonaceous shale beds 2 to 4 feet thick

Sandstone, brown, concretionary; gray sandy shale; and carbonaceous browti thate. At about the middle of this unit and hadf a mife the of the we of the section (U. S. G. S. lociality 10722) were found Nucula sp., Yotdia evansi Meek and Haydęn, Barbatia? sp. undescribed, Ostrea sp., Cardium (Ethmocardium) sp. undescribed, Mactra nitidula Meek and Hayden, Cuspidaria aff. C. moreauensis Meek and Hayden, uandetermined crab, and Echidnocephalus? sp................................. 11

Shale, brown, sandy 38

Shale, carbonaceous......................... 3

Sandstonè and gráy shăle

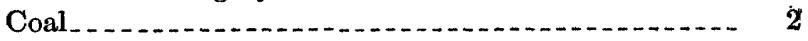

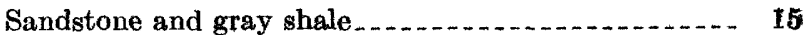

Shale, carbotaceous; contains at the middle (U. S. G. S. localities 10720, 12503) Ostrea glabra Meek...

Shale, gray, sandy, with brown coneretionary sandstone and beds of carbonaceous shale. From a soft sandstone 20 feet below the top Nacula sp., Anomia gryphaeiformis Stanton, Unio subspitulatus? Meek and Hayden, Unio danao? Meek and Hayden, Unio sp., Campeloma multilineata? Meek and Hayden, and Viviparus sp. (U. S. G. S. localities 102504, 10721); and Rhamnus williardi Knowlton, Quercus sp., Viburnum sp., and Orevdaphnet sp. (U. S. G. S. locality 7510)

Sandstoné, brown, concretionrry, marine; Halymenites abundant and fragments of shells..................

Shale, gray, sandy . . . . Shale, carbonaceous.... .

Shale, gray, and eotreretionary ardstone.........

Shale, carbonaceous. 
"Laramie" formation (part)-Continued.

Coal _. . . . . . - .

Shale, gray

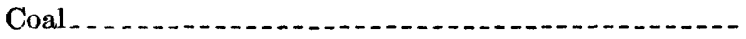

Shale, gray - . .

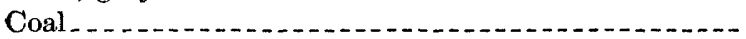

Shale, sandy, gray, and thin platy sandstone........

Shale, carbonaceous; contains Ostrea glabra Meek and Hayden (U. S. G. S. locality 12502)

Shale, gray, sandy, with numerous discontinuous ferruginous concretionary beds..................... 140

Sandstone, dark brown; massive to platy; contains Ostrea sp., Cardium speciosum Meek and Hayden, Baculites sp. (U. S. G. S. locality 12501) _....... Shale, sandy, dark brown . . . . . . Shale, sandy, gray, with a few sandstone lenses......Sandstone, brown, concretionary, contains macerated plant remains . . . . . . . . . . .

Shale, dark gray; weathers light colored.............

Sandstone, platy, calcareous . . . . . . . . . . .

Shale, gray, sandy

Sandstone, brown, concretionary; contains Ostrea sp., Cardium speciosum Meek and Hayden, and Corbula undifera Meek (U. S. G. S. locality 12500)

Sandstone, gray, platy

Shale, sandy, dark gray; weathers light colored......

Sandstone, grayish brown, concretionary ............

Lewis shale: Shale, gray, with minor thin beds of sandstone and calcareous concretions; contains Pierre fossils. Thickness not measured.

E. E. Smith and M. W. Ball ${ }^{49}$ collected at other localities in this area distinctive Fox Hills fossils from strata comparable to the uppermost marine beds of this section, and there is no doubt that the higher marine beds are of Fox Hills age. The lower beds are definitely of upper Pierre age. Plants collected from the nonmarine beds above the highest marine beds have been ascribed to the Laramie flora and given an age assignment older than that of the Lance beds, but an abundant invertebrate fauna is identical with that of the Lance of northeastern and central Wyoming. At no place in the sequence, either in the part described here or in considerable thicknesses above and below it, is there a plane suggesting an important interruption.

In the Hanna Basin ${ }^{50}$ the change from marine to nonmarine beds-from Lewis shale to Medicine Bow formation-is exactly parallel to the change near Rawlins from Lewis to "Laramie." A typical example is the section 5 miles north of Walcott, Wyo. Here massive light-gray to brown sandstone 270 feet thick rests on several thousand feet of marine Lewis shale. Upon the sandstone lies about 300 feet more of shale, poorly exposed but probably marine and included in the Lewis by Bowen; then 550 feet of shale, soft gray to brown sandstone, and some hard dark-brown sandstone, which is not very fossiliferous

\footnotetext{
49 Unpublished data.

50 For a general description see Bowen, C. F., Stratigraphy of the Hanna Basin, Wyo.: U. S. Geol. Survey Prof. Paper 108, pp. 227-235, 1918.
}

but yields a few oysters and scattered plant remains and forms the basal part of the Medicine Bow formation. Next above is a thin zone of hard brown concretionary sandstone with Fox Hills fossil, including Yoldia evansi Meek and Hayden, Yoldias sp., Ostrea sp., Anomia sp., Modiola sp. undescribed, Anatina aff. A. doddsi Henderson, Pholadomya subventricosa Meek and Hayden, Thracia subgracilis: Whitfield, Cardium speciosum Meek and Hayden, Tellina scitula Meek and Hayden, Legumen planulatum Conrad, Mactra cf. M. warrenana Meek and Hayden, Dentalium sp., Lunatia concinna Hall and Mee $\mathrm{M}^{\mathrm{r}}$, Haminea sp., Anisomyon? sp., and Sphenodiscus lenticulare (Owen) (U. S. G. S. locality 10723). At a horizon 15 feet higher (U. S. G. S. locality 10724) occur Ostrea glabra Meek and Hayden, Anomia gryphorhynchus Meek, and Corbicula sp.-a brackish-water faunaand at 15 feet higher still (U. S. G. S. loc $\bullet$ lity 10725) Ostrea glabra Meek and Hayden and Corbieula sp. Above these only plant remains were found in a hasty search, though fresh-water invertebrates are abundant at many places in the formation in adjacent sections. The flora of the Medicine Bow formatic has been identified with that of the Laramie of the $\mathrm{I}$-3nver Basin and has been considered pre-Lance in age. The same zone of marine beds as that noted at Wrlcott, or at least a very similar one, well above the base of the Medicine Bow formation, was noted by Stanton ${ }^{51}$ at several other places in the Hanna Basin, and there seems to be little doubt that a fairly thick transition zone of alternating marine and nonmarine deposits is widespread. A misinterpretation of the stratigraphy of this area ${ }^{52}$ by some of the earlier studen ts led to the concept of the presence here of a very geat unconformity comparable to the supposed pre-Lance and pre-Arapahoe unconformities, but the car ful restudy of the region by Bowen and others has shown that the only great unconformity in the section is at a much higher stratigraphic plane, the I ne of the Wasatch.

In this same general area the writers, with J. B. Eby, examined and measured the section on Muddy Creek near Dad, Wyo. Here is found essentially the same unbroken sequence from Lewis up into "Laramie."

For southern Wyoming as a whole the beds called "Laramie" or Medicine Bow are identical in lithology with those a short distance to the north, beyond the Sweetwater Mountains, which are accepted as Lance by everyone who has examined them; the same large nonmarine fauna occurs in both sets of beds and also the same Triceratops fauna; both succeed conformably

\footnotetext{
si Stanton, T. W., personst communication.

52 Veatch, A. C., Coal flelds of east-central Carbon County, Wyo.: U. S. Geol. Survey Bull. 316, p. 250, 1907. Fnowlton, F. H., Further data on the stratigraphic position of the Lance formation ("Ceratops beds"): Jour. Geolog $\mathrm{y}, \mathrm{vol}$. 19, pp. 359362, 1911; Cretaceous-Tertiary boundary in the Rocky Mountain region: Geol. Soc. Amorica Bull., vol. 25, p. 328, 1914.
} 
a zone containing the Sphenodiscus fauna of Fox Hills age. The only discordant note is that the flora of the Lance beds is said to be a Fort Union flora, whereas the flora of the "Laramie" or Medicine Bow formation is said to be a Laramie flora and older than Lance. Hares ${ }^{53}$ some years ago expressed ths opinion that the Lance of the Casper region and much of the Medicine Bow ("Lower Laramie") of southern Wyoming are equivalent, an opinion which the writers believe to be substantially correct.

\section{YAMPA VALLEY, COLO.}

An area of especial interest as being the farthest west in Colorado at which a typical Fox Hills fauna is known is in the Yampa Valley in the vicinity of Craig The section here includes a shale formation designated the Lewis shale, overlain by a formation still known, as are the similar beds in parts of southern Wyoming, by its old name "Laramie," originally applied because the upper part of it contains Laramie plants. ${ }^{54}$ The "Laramie" in Yampa Valloy begins with a massive sandstone, above which lie thin beds of shale and sandstone that include a coal bed and zones of marine and brackish-water fossils. These fossils, including Sphenodiscus, ${ }^{55}$ belong to the Fox Hills fauna and range as high as 350 feet above the base of the "Laramie," as the formation was originally identified and as the name is applied now for convenience in mapping. Above the marine beds are shale, sandstone, and thin beds of coal, an assemblage much like that which in Wyoming is called Medicine Bow and Lance, though it is much thinner. The upper boundary of the "Laramie" has been drawn beneath a conglomerate that marks the beginning of the "post-Laramie" formation-a unit that has a flora of Fort Union aspect and a lithology somewhat different from that of the "Laramie." There is no evidence of unconformity in the section except the presence of the conglomerateevidence of somewhat doubtful value.

\section{MORTHEASTERN COLORADO AND THE DENVER BASIN}

The Fox Hills sandstone has been interpreted in this general region as including a series of sandstones and sandy shales with a conspicuous sandstone at the top, the whole assigned a thickness stated by some geologists to be as much as 2,000 feet, though by others only 800 to 1,000 feet, the difference being due in part, perhaps, to difference in choice of basal boundary, in part to differences in calculation of thickness. The sandstone at the top was designated by Henderson ${ }^{56}$ the Milliken

os Hares, C. J., Correlation of some of the Cretaceous and Eocene formations of central Wyoming [abstract]: Washington Acad. Sel. Jour., vol. 5, pp. 328-330, 1915.

${ }^{64} \mathrm{Gale}, \mathrm{H}$. S., Coal fields of northwestern Colorado and northeastern Utah: U. S. Geol. Survey Bull. 415, pp. 72-74, 1910.

os Hancock, E. T., Geology and coal resources of the Axial and Monument Butte quadrangles, Moffat County, Colo.: U. S. Geol. Survey Bull. 757, p. 22, 1925.

56 Henderson, Junius, The Cretaceous formations of northeastern Colorado: Colorado Geol. Survey Bull. 19, p. 22, 1920. sandstone; and the suggedtion was made that its bo would have been chosen as the logical plane of $\$ \mathrm{~b}$ division of the Montana group had the group been $f$ tat studied in Colorado. The lower Fox Hills, taken in the usual sense as including beds well below the Milliken sandstone member, contains neither the fos most characteristic of the Fox Hills nor those mist. characteristic of the Pierre, but it does contain a famna: of species that occur in both Fox Hills and upper. Pier $\theta$; the Milliken sandstone itself contains the distinctive ammonite Sphenodiscus. It seems to the writers that only the Milliken and possibly any marine beds above. it should be considered strictly as of Fox Hills age and comparable to the typical,Fox Hills, though the grounds for this opinion are chiefly negative and therefore wenk. Even if the Fox Hills is conceded to be very thick, the value of this thickness as proof of erosion in other areas is reduced by the fact that the underlying Pierre shale has in this area an astonishingly great thickness, in comparison with which even the great thickness of the Fox Hills would not be disproportionate.

According to Henderson ${ }^{57}$ the Milliken sandstone consists of

massive, rather soft, usually greenish-yellow sandstone, from 100 to 150 feet in thickness, almost entirely free from shiles except a few 1-inch bands in the lower part. The sandstone contains many large brown coneretions and bands, more or less ferruginous and calcareous and usually highly fosiliferous. The more gentle slopes above are occupied by alternating shales and soft sandstones, containing marine fossils and not sharply separated from the overlying Laramie shales apd sandstones. The Laramie is not well exposed in this region, owing larpaly to the absence or weakness of the massive thick white ndstone, which is such a conapicuous and persistent feature of the lower Laramie in Boulder County.

In the Denver Basin the Milliken sandstone is orarlain by two grayish-white sandstones, each about 60 feet thick, separated by about 4 feet of lignitic shale, which passes into coal in some places. A third and much whiter sandstone, about 10 feet thick, occurs 60 feet higher in the section and is a good marker in coal exploration because all workable beds in the lo part of the Laramie formation of the Denver field occur below it. ${ }^{\text {s8 }}$

The rock sequence as thus described might suggest that the Milliken sandstone is to be correlated with the basal brownish sandstone of the northern Fox Hills; that the coal-bearing white sandstones of the brsal Laramie of the Denver Basin and northeastern Colorado are to be correlated with the Colgate sandstone member of the Fox Hills as developed in eastern Wyoming, eastern Montana, and the Dakotas; and that the Laramie clays are equivalent to the Hell Creek member of the Lance. Such long-range correlations on lithology alone are very uncertain, but it

$\$ 7$ Henderson, Junius, op. elt., p. 23.

${ }_{58}$ Emmons, S. F., Cro3s, Whitman, an 1 Eldridge, G. H., Geolagy of the be nver Basin in Colorado: U. 8. Geol. Survey Mon. 27, pp. 73-74, 1896. 
is on other grounds as neanly certain as such matters can be that the Milliken is equivalent to some part of the typical Fox Hills. The view that the Laramie clays are of the same age as the Hell Creek member of the Lance is supported, as Stanton long ago pointed out, by the invertebrate fauna and by the recent finding in the Laramie beds near Briggsdale, Colo., ${ }^{59}$ of several horn cores identified as probably Triceratops. The differences cited between the fossil floras of the Laramie and the Lance are no more impressive than those cited between the floras of the Denver and the Lance or Fort Union, both assigned to the Eocene by Knowlton.

No one has ever reported any evidence of unconformity between the Fox Hills and Laramie, and this fact, with the assignment of a great thickness to the Fox Hills, has been used as an argument that the Laramie and most of the Fox Hills were removed by pre-Lance erosion at places outside of the Denver Basin where no Laramie, as such, is recognized and the accepted Fox Hills is thin. If, however, the Laramie-Arapahoe unconformity represents a short interval, comparable to some of those represented by the admittedly minor unconformities within both Fox Hills and Lance formations, the Laramie, Arapahoe, and Denver with their Triceratops fauna become a logical equivalent for some part of the Lance, and the sections in the Denver Basin and in the northern plains match. Hay ${ }^{60}$ and Stanton ${ }^{61}$ long ago expressed the opinion that the unconformity noted between the Laramie and Arapahoe formations is not of stratigraphic importance-an opinion with which the writers fully agree.

The emphasis that has been laid by some writers on the importance of the unconformity between the Laramie and the Arapahoe rests, as stated on page 10, upon the propositions (1) that in the Rocky Mountain region the Cretaceous sea was unbroken by any islands and undisturbed by any regressions from its entrance into the region in early Upper Cretaceous time until its withdrawal in late Upper Cretaceous time and (2) that the conglomerate of the Arapahoe contains pebbles derived from near-by exposures of practically all the pre-Arapahoe rocks-a necessary corollary being that between the deposition of the last Cretaceous beds and the beginning of the Arapahoe there must have occurred the elevation and erosion of the whole preceding section of some 12,000 feet. The first proposition would certainly not be accepted by students of the Interior Cretaceous to-day. The second appears to the writers highly debatable. Even if the identification of the pebbles as pre-Cambrian, "Red Beds," Dakota, Niobrara, Laramie, etc., is

\footnotetext{
50 Toepelman, W. C., Notes on the Laramie formation in central Weld County, Colo.: Jour. Geology, vol. 34, p. 834, 1926.

"0 Hay, O. P., Where do the Lance Creek ("Ceratops") beds belong, in the Cretaceous or in the Tertiary?: Indiana Acad. Sci. Proc. for 1909, p. 284, 1910.

61 Stanton, T. W., Boundary between Cretaceous and Tertiary in North America as indicated by stratigraphy and invertebrate faunas: Geol. Soc. America Bull., vol. 25, pp. 347-348, 1914.
}

granted-which appears not beyond some doubt, considering the types of rocks concerned-it is still a gratuitous assumption that they had to come from sources near enough to exclude any possible areas af Cretaceous erosion. The demand for a Fost-Laramie time interval long enough to permit elovation and erosion of the whole thickness of pre-Arapahae sediments is too great a strain on the known facts, such as the occurrence of very similar if not identical ceratopsian dinosaurs in the Laramie and in the Arapahoe and Denver beds. The cited differences of the Laramie and post-Laramie in the floras are not impressive, in view of the differences in time and in physical conditions supposed to exist-in fact, they ar no greater than those existing between the supposed Tertiary Arapahoe-Denver flora on the one hand and the supposed Tertiary Lance-Fort Union flora on the other, the latter said by the paleobotanists to be essentially one flora, though occurring through a great thickness of strata in which marked changes take placo in the contained invertebrate and vertebrate faunas.

\section{WESTERN AND SOUTHERN MARGINS OF THE IATMERTOR BEGION}

In New Mexico, Arizona, Utạh, and wastern Wyoming any beds of Fox Hills age that may be present are nonmarine and do not differ sufficiently in either lithologic constitution or faunal content from associated beds older or younger than the Fox Hills to permit any useful comparison to be made. In some regrions, such as the San Juan Basin and the Raton coal field, New Mexico, unconformities are recognized within the series of nonmarine beds, but their relative importance can not now be determined. In the San Juan Bosin dinosaur remains of very closaly allied types occur both below and above the most conspicuous unconformity, suggesting that it is not very significant.

\section{CONSTITUTION OF THE COLGATE SANDSTONE MEMAER OF MTIE DOX HLLS SANDSTONE}

The record of voloanic ash in the Fox Hills sandstone east of the Missouri River near Linton, N. Dak., by Stanton ${ }^{62}$ led to the suspicion that the white color of the Colgate sandstone might be due to a content of volcanic ash, and to the hope that the ash might afford a basis for definite correlation.

The deposit-near Linton is deseribed as.consisting of chalk-white strata some 26 feet thick and 35 feet above the base of the Fox Hills sandstone. Sperimens from this deposit were examined by G. F. Loughlin, who reported them to contain 80 per cent of volcanic glass, 15 per cent of quartz and feldspar, 2 or 3 per cent of biotite, and scattered grains of other mine-als. About 16 feet higher in the section is a greenalite bed that also contains volcanic glass. The nearest porsible source

os Stanton, T. W., A Cretaceous volcanic ash bed on the Great Plains in North Dakota: Washington Acad. Sci. Jour., vol. 7, pp. 80-81, 1917. 
of the glass now known is far to the west, in the Livingston region of Montana.

Clarence S. Ross examined specimens of white Colgate sandstone obtained in T. 21 N., R. 32 E., Mont., but found no evidence of volcanic material, as the following memorandum submitted by him indicates:

The specimens of Colgate sandstone examined are composed of a great variety of detrital materials. Sand grains form about one-third, and claylike material the remainder of a typical specimen. Quartz is the most abundant single mineral element in the sand grains, but minor amounts of microcline, plagioclase, muscovite, biotite, chlorite, tourmaline, garnet, zircon, and apatite are present. The materials are not well sorted and range from 0.3 to 0.01 millimeter or less in diameter. Large grains are in direct contact with small ones, and there is no evidence of concentration of large or small grains along bedding planes. The sand grains are nearly all sharply angular.

Some specimens contain several per cent of calcite, and others contain almost none. Some of this is probably of detrital origin, but euhedral rhombs of calcite and 'sparse grains of glauconite were probably formed during the deposition of the sediments.

The material between the quartz grains is of the most heterogeneous nature. Most of it was not deposited as fine sediment but forms individual grains that have about the same diameter as the quartz. Much of it resembles the detrital material derived from more or less metamorphosed sediments, and the ferromagnesian minerals are those characteristic of metamorphic rocks. Some of the grains appear to be fine-grained quartzite, and others are chert or jasperlike quartz. Many grains are probably highly indurated shale; others resemble a sericitized rock, and some of the larger quartz grains appear to be partly sericitized. Qualitative chemical tests of the interstitial material show the presence of essential amounts of potash, and this indicates that this material is partly mica.

Clay minerals make up a considerable part of the interstitial material, and most of these appear to have formed in place by the alteration of detrital rock grains. At least two clay minerals are recognizable. The more abundant is a mineral of the kaolin group that is probably leverrierite or anauxite, ${ }^{63}$ and the other is beidellite. ${ }^{64}$

The sandstone is nearly white, notwithstanding the fact that it contains grains of brown and other dark colors. Its light color is due to the white, chalklike appearance of the sericite and clay present as interstitial material between the grains of quartz-that is, the color of the sandstone is due to the tinting power of the large proportion of white interstitial material and not to freedom from impurities.

63 Dittler, E., and Hibsch, J. E., Min. pet. Mitt., vol. 36, p. 85, 1923.

${ }_{04}$ Ross, C. S., and Shannon, E. V., Washington Acad. Sei. Jour., vol. 15, p. 467,

\section{SUMMARY OF CONCLUSIONS}

The writers believe that the foregoing description of the contact of the Fox Hills and Lance formations and of units equivalent to these formations in areas where other names are used, together covering a large part of the Western Interior of the United States, supports the following statements:

The contact of the Lance and Fox Hills is everywhere essentially transitional.

All angular unconformities reported to exist between these formations are misinterpretations of faulting, cross-bedding, or slumping.

Erosion planes in the Fox Hills and Lance formations are unimportant chronologically, being merely evic'snce of local channeling of near-shore deposits by tidal currents and wave scour in the Fox Hills or of frodplain deposits by streams in the Lance-that is the result of contemporaneous erosion and redeposition.

The localities of certain collections of plants identified as belonging to the Fort Union flora and hitl arto considered to occur higher than the "unconform ity" above the Fox Hills are really in the upper part of the Fox Hills sandstone.

The Fox Hills sandstone, from its type region at Fox Ridge, between the Cheyenne and Moreau Rivers, S. Dak., westward at least as far as the Musselshell River, Mont., and southward as far as Glenrock, Wyo., consists usually of a variable lower membar of yellowish-brown marine sandstone and sandy shale and a variable upper member of white sandstone, which is locally of marine origin, though at some places it contains coal and plant remains; above the upper member at most localities occur beds of coal of variable purity, which belong to the Lance formation.

The Laramie and Arapahoe formations and at least part of the Denver formation of the Denver Basin, most of the Medicine Bow formation of southern Wyoming, and the "Laramie" formation of northwestern Colorado, conformable on beds of Fox Hills age, are equivalent to the Lance formation.

The white color of the Colgate member of the Fox Hills sandstone does not appear to be due to a cortent of volcanic ash, and the formations therefore can not be correlated on this basis. 
